\title{
Article \\ Age-Related Changes in the Matrisome of the Mouse Skeletal Muscle
}

\author{
Francesco Demetrio Lofaro ${ }^{1,+}$, Barbara Cisterna ${ }^{2,+} \mathbb{D}$, Maria Assunta Lacavalla ${ }^{2} \mathbb{D}$, Federico Boschi ${ }^{3} \mathbb{D}$, \\ Manuela Malatesta ${ }^{2}$, Daniela Quaglino ${ }^{1}$ (D) Carlo Zancanaro ${ }^{2} * \mathbb{D}$ and Federica Boraldi ${ }^{1, *(D)}$
}

1 Department of Life Sciences, University of Modena and Reggio Emilia, I-44100 Modena, Italy; francescodemetrio.lofaro@unimore.it (F.D.L.); daniela.quaglino@unimore.it (D.Q.)

2 Department of Neurological and Movement Sciences, University of Verona, I-37100 Verona, Italy; barbara.cisterna@univr.it (B.C.); mariaassunta.lacavalla@univr.it (M.A.L.); manuela.malatesta@univr.it (M.M.)

3 Department of Computer Science, University of Verona, I-37100 Verona, Italy; federico.boschi@univr.it

* Correspondence: carlo.zancanaro@univr.it (C.Z.); federica.boraldi@unimore.it (F.B.)

+ Equal contribution.

check for updates

Citation: Lofaro, F.D.; Cisterna, B.; Lacavalla, M.A.; Boschi, F.;

Malatesta, M.; Quaglino, D.;

Zancanaro, C.; Boraldi, F.

Age-Related Changes in the

Matrisome of the Mouse Skeletal Muscle. Int. J. Mol. Sci. 2021, 22, 10564. https://doi.org/10.3390/ ijms221910564

Academic Editor:

Manuel Vázquez-Carrera

Received: 5 September 2021

Accepted: 27 September 2021

Published: 29 September 2021

Publisher's Note: MDPI stays neutral with regard to jurisdictional claims in published maps and institutional affiliations.

Copyright: (c) 2021 by the authors. Licensee MDPI, Basel, Switzerland. This article is an open access article distributed under the terms and conditions of the Creative Commons Attribution (CC BY) license (https:// creativecommons.org/licenses/by/ $4.0 /)$.

\begin{abstract}
Aging is characterized by a progressive decline of skeletal muscle (SM) mass and strength which may lead to sarcopenia in older persons. To date, a limited number of studies have been performed in the old SM looking at the whole, complex network of the extracellular matrix (i.e., matrisome) and its aging-associated changes. In this study, skeletal muscle proteins were isolated from whole gastrocnemius muscles of adult (12 mo.) and old (24 mo.) mice using three sequential extractions, each one analyzed by liquid chromatography with tandem mass spectrometry. Muscle sections were investigated using fluorescence- and transmission electron microscopy. This study provided the first characterization of the matrisome in the old SM demonstrating several statistically significantly increased matrisome proteins in the old vs. adult SM. Several proteomic findings were confirmed and expanded by morphological data. The current findings shed new light on the mutually cooperative interplay between cells and the extracellular environment in the aging SM. These data open the door for a better understanding of the mechanisms modulating myocellular behavior in aging (e.g., by altering mechano-sensing stimuli as well as signaling pathways) and their contribution to age-dependent muscle dysfunction.
\end{abstract}

Keywords: aging; extracellular matrix; proteomics; ultrastructure; immunohistochemistry; sarcopenia

\section{Introduction}

Skeletal muscle (SM) is necessary for locomotion, but it also plays important roles in several physiological processes such as bone homeostasis, thermogenesis, and metabolism of amino acids, glucose, and lipids [1,2]. The progressive loss of muscle strength and mass, alterations in tissue composition, and increasing denervation can lead to the development of sarcopenia, a pathological condition which generally occurs in aging but can also occur at a young age $[3,4]$. Sarcopenia contributes to a lower quality of life since, for example, the risk of falls with consequent fractures and loss of independence increases and may contribute to the development of type II diabetes and of metabolic syndrome [5].

Over the past decades, many studies have shown that sarcopenia is a multifactorial process [6] involving, among other factors: (i) reduction in the size and the number of myofibers [7]; (ii) satellite cell (SC) exhaustion and altered immune and muscle cell crosstalk (necessary for muscle proliferative and regenerative capacity) [8]; (iii) mitochondria dysfunction causing inefficient energy production [9]; (iv) alterations in insulin-like growth factor 1, Notch, and Wnt/beta-catenin signaling pathways [3]; (v) increase of oxidative stress [10]; and (vi) dysregulation of protein synthesis and degradation [11].

The extracellular matrix (ECM) is composed of different groups of macromolecules such as collagens, non-collagenous glycoproteins (e.g., laminin, tenascin, and fibronectin), 
glycosaminoglycans (e.g., heparan sulfate), and proteoglycans (e.g., biglycan and lumican) [12]. These macromolecules bind to each other and to cells through integrins, sarcoglycan complex, and dystroglycan to form an intricate network sending biochemical signals to myofibres. ECM regulates several cell functions (e.g., growth, differentiation, and migration) [13] and represents the structural and functional support for muscle fibers, vessels, and nerves, playing a role in the transmission of contractile forces [14], as well as muscle development [15], growth, and repair [16]. ECM is affected by the aging process in terms of turnover and ratio of specific components, the balance between synthesis and degradation of components, modifications in cellular behavior through altered cell-matrix interactions, and changes in mechano-sensing pathways. In age-dependent sarcopenia, changes in ECM architecture and composition and fibrosis [17] are believed to reduce the regenerative capacity of SM and to negatively influence the proliferation and differentiation capability of SC $[12,18-20]$. The ECM remodeling in sarcopenia has also been linked to mitochondrial deterioration [9,19]. However, until now, a limited number of investigations have been performed in the aging SM looking at the matrisome as the whole complex network of ECM molecules.

In recent years, thanks to the development of mass spectrometry (MS)-based highthroughput proteomic techniques, large-scale protein characterization is less challenging. Proteomic approaches have been successfully applied to SM in different experimental models [21-24]. However, to date, there is little information available on ECM proteins of SM [25] and their aging-associated changes.

The identification and quantification of ECM components and their interactions are essential steps to understand the role of the matrisome in sarcopenia. In this context, we decided to investigate the SM ECM in old compared to adult mice. We are aware that it would be of interest to analyze life-long changes, and thus also include muscles from young animals. However, it has to be underlined that most changes in muscle protein expression are known to take place after middle age [24].

The morphology of old SM has been already characterized in previous work from our laboratory highlighting several typical features of the sarcopenic condition. A significantly smaller myofiber cross-sectional area was observed in the SM of old mice $[26,27]$. Although the general cytological organization of the old myofiber was not grossly altered, morphometrical studies highlighted several age-related modifications (e.g., accumulation of larger inter-myofibrillar and sub-sarcolemmal mitochondria, larger myonuclei with increased condensed chromatin, impairment of RNA maturation/export pathways, decreased amount of active satellite cells) [28-30]. In this work, the gastrocnemius muscle was selected for analysis since it is prevalently composed of fast-twitch fibers [27], which are especially affected by atrophy during aging.

Therefore, to shed light on age-related changes in the matrisome of the gastrocnemius muscle, we combined a proteomic approach (i.e., liquid chromatography (LC)-MS/MS and bioinformatic analyses) with morphological and morphometrical evaluations of sections observed by fluorescence and transmission electron microscopy.

Results provided novel characterization of the aging matrisome. Higher amounts of several ECM proteins in old vs. adult muscle were demonstrated, thereby shedding new light on the mutually cooperative interplay between cells and the extracellular environment. This study opens the door to a better understanding of the mechanisms modulating myocellular behavior (e.g., alteration of mechano-sensing stimuli and/or signaling pathways).

\section{Results}

\subsection{Identification of Proteins in the Gastrocnemius Muscle}

In this study, samples of gastrocnemius muscle were subjected to three sequential extractions, each one being analyzed by LC-MS/MS. In particular, phosphate buffer saline (PBS) was used to solubilize hydrophilic proteins (PBS extract), and then the insoluble part was treated with a combination of urea $(\mathrm{U})$ and thiourea $(\mathrm{T})$ to extract hydrophobic molecules such as membrane proteins, myofibrillar, and part of ECM proteins (U/T 
extract) [31]. Finally, the remaining insoluble fraction was treated with guanidine- $\mathrm{HCl}$ ( $\mathrm{GuHCl}$ extract), one of the most efficient chaotropic agents which is known to extract poorly soluble, heavily cross-linked proteins, and proteoglycans. This approach has been reported to improve protein extraction from ECM-rich tissues (e.g., cartilage, tendon) $[32,33]$ (Figure 1a).

a

a

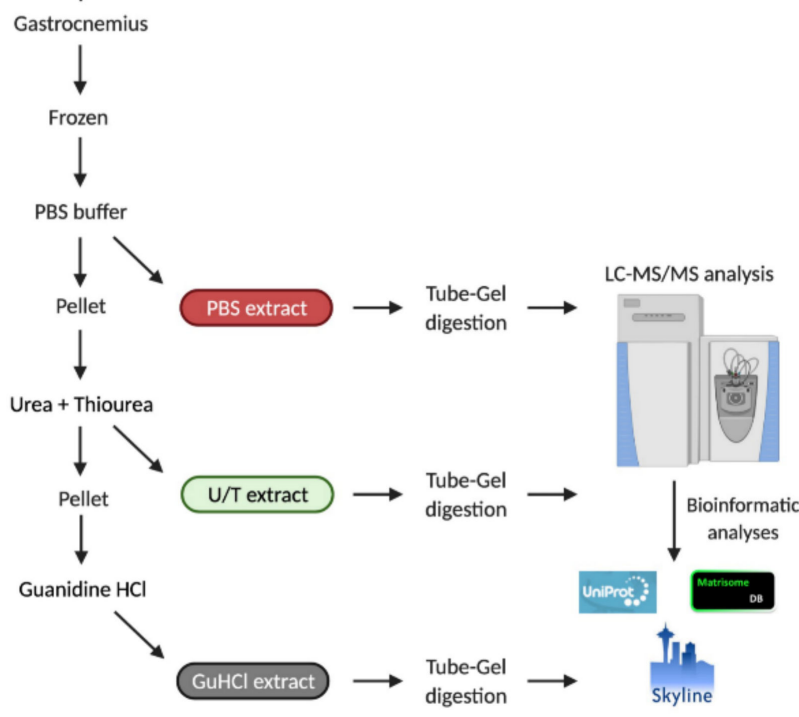

b

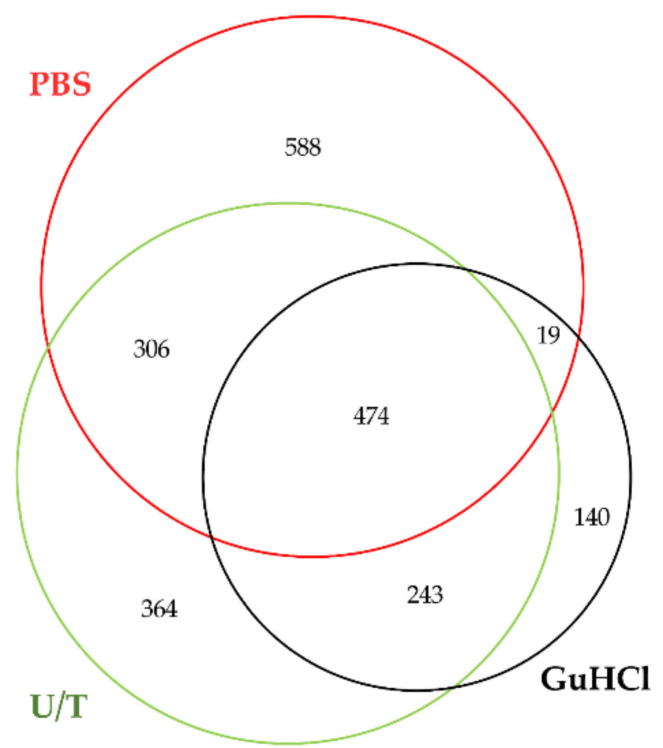

Figure 1. (a) Sequential protein extraction from gastrocnemius muscle. (b) The Venn diagram shows the number of proteins identified in each extract.

This strategy allowed us to identify, with at least 1 unique peptide, 2134 different proteins (Table S1) of which 474 were identified in all 3 extracts, while 588, 364, and 140 proteins were detected in the PBS, $\mathrm{U} / \mathrm{T}$, and $\mathrm{GuHCl}$ extracts, respectively (Figure 1b).

To reveal the ECM composition of the gastrocnemius muscle, the 2134 identified proteins were further analyzed by interrogating the MatrisomeDB, a database that includes all structural ECM components and proteins that may directly or indirectly interact with the ECM [34]. The matrisome is constituted by a "core matrisome", comprising collagens, proteoglycans, and glycoproteins, and by "matrisome-associated proteins", which include secreted factors, ECM-affiliated proteins, and ECM regulators [35]. As shown in Table 1, 124 proteins were found to be part of ECM; in particular, 14, 38, and 10 proteins belong to the collagen, glycoprotein, and proteoglycan category, respectively. Sixty-two proteins constituted the "matrisome-associated proteins" (i.e., 15, 37, and 10 proteins representing ECM-affiliated proteins, ECM regulators, and secreted factors, respectively). 43\% (54/124) of proteins were found only after $\mathrm{U} / \mathrm{T}$ and $\mathrm{GuHCl}$ extract of which 28 polypeptides were identified in both extracts (i.e., $\mathrm{U} / \mathrm{T}$ and $\mathrm{GuHCl}$ ) and 13 only with $\mathrm{U} / \mathrm{T}$ or with $\mathrm{GuHCl}$ buffer. 
Table 1. ECM and ECM-associated components from the gastrocnemius muscle categorized according to MatrisomeDB.

\begin{tabular}{|c|c|c|c|}
\hline Protein Symbol & Protein Name & Protein Symbol & Protein Name \\
\hline \multicolumn{4}{|c|}{ MATRISOME DIVISION: CORE MATRISOME } \\
\hline \multicolumn{4}{|l|}{ Category: collagen } \\
\hline CO1A1 & Collagen alpha-1(I) chain & CO6A1 & Collagen alpha-1(VI) chain \\
\hline CO1A2 & Collagen alpha-2(I) chain & CO6A2 & Collagen alpha-2(VI) chain \\
\hline CO3A1 & Collagen alpha-1(III) chain & CO6A6 & Collagen alpha-6(VI) chain \\
\hline CO4A1 & Collagen alpha-1(IV) chain & COBA1 & Collagen alpha- $1(\mathrm{XI})$ chain \\
\hline $\mathrm{CO} 4 \mathrm{~A} 2$ & Collagen alpha-2(IV) chain & COEA1 & Collagen alpha- $1(\mathrm{XIV})$ chain \\
\hline CO5A1 & Collagen alpha-1(V) chain & COFA1 & Collagen alpha- $1(\mathrm{XV})$ chain \\
\hline $\mathrm{CO} 5 \mathrm{~A} 2$ & Collagen alpha-2(V) chain & COIA1 & Collagen alpha-1(XVIII) chain \\
\hline \multicolumn{4}{|c|}{ Category: ECM-glycoproteins } \\
\hline ADIPO & Adiponectin & LAMB1 & Laminin subunit beta-1 \\
\hline AGRIN & Agrin & LAMB2 & Laminin subunit beta-2 \\
\hline BGH3 & $\begin{array}{l}\text { Transforming growth factor-beta-induced } \\
\text { protein ig-h3 }\end{array}$ & LAMC1 & Laminin subunit gamma-1 \\
\hline CILP1 & Cartilage intermediate layer protein 1 & MFAP2 & Microfibrillar-associated protein 2 \\
\hline CILP2 & Cartilage intermediate layer protein 2 & MFAP4 & Microfibril-associated glycoprotein 4 \\
\hline COMP & Cartilage oligomeric matrix protein & MFAP5 & Microfibrillar-associated protein 5 \\
\hline CREL1 & $\begin{array}{l}\text { Cysteine-rich with EGF-like domain } \\
\text { protein } 1\end{array}$ & MFGM & Lactadherin \\
\hline DERM & Dermatopontin & NID1 & Nidogen-1 \\
\hline FBN1 & Fibrillin-1 & NID2 & Nidogen-2 \\
\hline FBN2 & Fibrillin-2 & POSTN & Periostin \\
\hline FIBA & Fibrinogen alpha chain & SLIT2 & Slit homolog 2 protein \\
\hline FIBB & Fibrinogen beta chain & SRPX & Sushi-repeat-containing protein SRPX \\
\hline FIBG & Fibrinogen gamma chain & SSPO & SCO-spondin \\
\hline FINC & Fibronectin & TENA & Tenascin \\
\hline IGS10 & Immunoglobulin superfamily member 10 & TINAL & Tubulointerstitial nephritis antigen-like \\
\hline LAMA2 & Laminin subunit alpha-2 & TSP1 & Thrombospondin-1 \\
\hline LAMA3 & Laminin subunit alpha-3 & TSP4 & Thrombospondin-4 \\
\hline LAMA4 & Laminin subunit alpha-4 & VMA5A & $\begin{array}{l}\text { von Willebrand factor A domain-containing } \\
\text { protein } 5 \mathrm{~A}\end{array}$ \\
\hline LAMA5 & Laminin subunit alpha-5 & VWA1 & $\begin{array}{l}\text { von Willebrand factor A domain-containing } \\
\text { protein } 1\end{array}$ \\
\hline \multicolumn{4}{|c|}{ Category: Proteoglycans } \\
\hline ASPN & Asporin & PGBM & $\begin{array}{l}\text { Basement membrane-specific heparan sulfate } \\
\text { proteoglycan core protein }\end{array}$ \\
\hline CHADL & Chondroadherin-like protein & PGS1 & Biglycan \\
\hline FMOD & Fibromodulin & PGS2 & Decorin \\
\hline LUM & Lumican & PRELP & Prolargin \\
\hline MIME & Mimecan & PRG2 & Bone marrow proteoglycan \\
\hline \multicolumn{4}{|c|}{ MATRISOME DIVISION: MATRISOME-ASSOCIATED PROTEINS } \\
\hline \multicolumn{4}{|c|}{ Category: ECM affiliated proteins } \\
\hline ANXA1 & Annexin A1 & GPC1 & Glypican-1 \\
\hline ANXA2 & Annexin A2 & HEMO & Hemopexin \\
\hline ANXA3 & Annexin A3 & LEG1 & Galectin-1 \\
\hline ANXA4 & Annexin A4 & LEGL & Galectin-related protein \\
\hline ANXA5 & Annexin A5 & LMAN1 & Protein ERGIC-53 \\
\hline ANXA6 & Annexin A6 & PLXA4 & Plexin-A4 \\
\hline ANXA7 & Annexin A7 & PLXB3 & Plexin-B3 \\
\hline ANX11 & Annexin A11 & & \\
\hline
\end{tabular}


Table 1. Cont.

\begin{tabular}{|c|c|c|c|}
\hline Protein Symbol & Protein Name & Protein Symbol & Protein Name \\
\hline \multicolumn{4}{|c|}{ Category: ECM regulators } \\
\hline A1AT1 & Alpha-1-antitrypsin 1-1 & ITIH1 & Inter-alpha-trypsin inhibitor heavy chain $\mathrm{H} 1$ \\
\hline A1AT2 & Alpha-1-antitrypsin 1-2 & ITIH2 & Inter-alpha-trypsin inhibitor heavy chain $\mathrm{H} 2$ \\
\hline A1AT3 & Alpha-1-antitrypsin 1-3 & ITIH3 & Inter-alpha-trypsin inhibitor heavy chain $\mathrm{H} 3$ \\
\hline A1AT4 & Alpha-1-antitrypsin 1-4 & ITIH4 & Inter alpha-trypsin inhibitor, heavy chain 4 \\
\hline $\mathrm{A} 2 \mathrm{AP}$ & Alpha-2-antiplasmin & ITIH5 & Inter-alpha-trypsin inhibitor heavy chain $\mathrm{H} 5$ \\
\hline AMBP & Protein AMBP & KNG1 & Kininogen-1 \\
\hline ANGT & Angiotensinogen & MMP17 & Matrix metalloproteinase-17 \\
\hline ANT3 & Antithrombin-III & PEDF & Pigment epithelium-derived factor \\
\hline CATB & Cathepsin B & PLMN & Plasminogen \\
\hline CATD & Cathepsin D & PZP & Pregnancy zone protein \\
\hline CBG & Corticosteroid-binding globulin & SERPH & Serpin H1 \\
\hline CPN2 & Carboxypeptidase $\mathrm{N}$ subunit 2 & SPA3K & Serine protease inhibitor $\mathrm{A} 3 \mathrm{~K}$ \\
\hline CYTB & Cystatin-B & SPA3M & Serine protease inhibitor A3M \\
\hline FA12 & Coagulation factor XII & SPA3N & Serine protease inhibitor $\mathrm{A} 3 \mathrm{~N}$ \\
\hline HEP2 & Heparin cofactor 2 & SPI2 & Serpin I2 \\
\hline HRG & Histidine-rich glycoprotein & SULF2 & Extracellular sulfatase Sulf-2 \\
\hline HYAL2 & Hyaluronidase-2 & TGM2 & $\begin{array}{l}\text { Protein-glutamine } \\
\text { gamma-glutamyltransferase } 2\end{array}$ \\
\hline IC1 & Plasma protease $\mathrm{C} 1$ inhibitor & THRB & Prothrombin \\
\hline ILEUA & Leukocyte elastase inhibitor A & & \\
\hline \multicolumn{4}{|c|}{ Category: secreted factors } \\
\hline ANGL7 & Angiopoietin-related protein 7 & S10A1 & Protein S100-A1 \\
\hline FILA2 & Filaggrin-2 & S10A4 & Protein S100-A4 \\
\hline HGFA & Hepatocyte growth factor activator & S10A6 & Protein S100-A6 \\
\hline INHBA & Inhibin beta A chain & S10AA & Protein S100-A10 \\
\hline MEG11 & $\begin{array}{l}\text { Multiple epidermal growth factor-like } \\
\text { domains protein } 11\end{array}$ & WN10A & Protein Wnt-10a \\
\hline
\end{tabular}

\subsection{Matrisome Quantification: Old SM vs. Adult SM}

To compare the relative abundance of matrisome proteins between adult and old muscle, we performed a label-free quantification, which was based on the measure of precursor ion intensities. Even though protein quantification can be performed on proteins identified with a single peptide [36], we preferred to quantify matrisome proteins which were identified with at least two peptides (i.e., 91/124 proteins) (for more details see material and methods) (Table S2), as only one peptide can be incorrectly quantified across LC-MS runs [37].

Table 2 lists only proteins that changed significantly between old and adult muscles (i.e., 18, 21, and 3 in PBS, U/T, and $\mathrm{GuHCl}$ extracts, respectively). Except for AnnexinA6, whose amount was significantly lower in aging SM, all other listed proteins were statistically significantly more abundant in old vs. adult SM. No statistically significant changes were found for proteins belonging to the category of secreted factors. 
Table 2. List of matrisome proteins whose amount statistically significantly changed in old vs. adult gastrocnemius muscles.

Quantification was performed by label-free mass spectrometry.

\begin{tabular}{|c|c|c|c|c|}
\hline \multicolumn{5}{|c|}{ PBS Extract } \\
\hline Category & Protein Symbol & Protein Name & $\begin{array}{l}\text { Ratio (Old/Adult) } \\
\log _{2} \text { Fold Change }\end{array}$ & $p$-Value \\
\hline \multirow{11}{*}{ ECM regulators } & A1AT2 & Alpha-1-antitrypsin 1-2 & 0.69 & 0.006 \\
\hline & $\mathrm{A} 2 \mathrm{AP}$ & Alpha-2-antiplasmin & 1.04 & 0.038 \\
\hline & CATD & Cathepsin D & 0.58 & 0.001 \\
\hline & CBG & Corticosteroid-binding globulin & 1.82 & 0.049 \\
\hline & ILEUA & Leukocyte elastase inhibitor A & 1.11 & 0.008 \\
\hline & ITIH2 & Inter-alpha-trypsin inhibitor heavy chain $\mathrm{H} 2$ & 2.00 & 0.038 \\
\hline & ITIH4 & Inter alpha-trypsin inhibitor, heavy chain 4 & 1.42 & 0.018 \\
\hline & KNG1 & Kininogen-1 & 0.97 & 0.043 \\
\hline & PEDF & Pigment epithelium-derived factor & 1.11 & 0.040 \\
\hline & PZP & Pregnancy zone protein & 0.86 & 0.012 \\
\hline & SPA3N & Serine protease inhibitor $\mathrm{A} 3 \mathrm{~N}$ & 1.77 & 0.028 \\
\hline \multirow{5}{*}{$\begin{array}{c}\text { ECM } \\
\text { glycoproteins }\end{array}$} & FIBA & Fibrinogen alpha chain & 1.19 & 0.001 \\
\hline & FIBB & Fibrinogen beta chain & 1.19 & 0.001 \\
\hline & FIBG & Fibrinogen gamma chain & 1.14 & 0.001 \\
\hline & TSP4 & Thrombospondin-4 & 1.44 & 0.000 \\
\hline & VMA5A & $\begin{array}{l}\text { von Willebrand factor A domain-containing } \\
\text { protein } 5 \mathrm{~A}\end{array}$ & 0.81 & 0.000 \\
\hline \multirow{3}{*}{ Proteoglycans } & ASPN & Asporin & 0.53 & 0.004 \\
\hline & LUM & Lumican & 0.48 & 0.030 \\
\hline & PRELP & Prolargin & 0.37 & 0.001 \\
\hline \multirow{5}{*}{$\begin{array}{l}\text { ECM affiliated } \\
\text { proteins }\end{array}$} & ANXA4 & Annexin A4 & 0.63 & 0.002 \\
\hline & ANXA5 & Annexin A5 & 0.51 & 0.009 \\
\hline & ANXA6 & Annexin A6 & -0.39 & 0.008 \\
\hline & ANX11 & Annexin A11 & 0.28 & 0.021 \\
\hline & HEMO & Hemopexin & 0.74 & 0.018 \\
\hline \multicolumn{5}{|c|}{ U/T Extract } \\
\hline \multirow{3}{*}{ Collagen } & CO4A1 & Collagen alpha-1(IV) chain & 1.30 & 0.016 \\
\hline & CO6A1 & Collagen alpha-1(VI) chain & 0.61 & 0.000 \\
\hline & CO6A2 & Collagen alpha-2(VI) chain & 0.59 & 0.001 \\
\hline \multirow{3}{*}{ ECM regulators } & A1AT2 & Alpha-1-antitrypsin 1-2 & 0.87 & 0.022 \\
\hline & CATD & Cathepsin D & 1.04 & 0.000 \\
\hline & TGM2 & $\begin{array}{l}\text { Protein-glutamine } \\
\text { gamma-glutamyltransferase } 2\end{array}$ & 0.80 & 0.013 \\
\hline \multirow{14}{*}{$\begin{array}{c}\text { ECM } \\
\text { glycoproteins }\end{array}$} & BGH3 & $\begin{array}{l}\text { Transforming growth factor-beta-induced } \\
\text { protein ig-h3 }\end{array}$ & 0.78 & 0.016 \\
\hline & CILP1 & Cartilage intermediate layer protein 1 & 1.47 & 0.000 \\
\hline & DERM & Dermatopontin & 0.51 & 0.004 \\
\hline & FINC & Fibronectin & 1.35 & 0.036 \\
\hline & LAMA2 & Laminin subunit alpha-2 & 0.45 & 0.000 \\
\hline & LAMA5 & Laminin subunit alpha-5 & 0.79 & 0.002 \\
\hline & LAMB1 & Laminin subunit beta-1 & 0.47 & 0.010 \\
\hline & LAMB2 & Laminin subunit beta-2 & 0.53 & 0.000 \\
\hline & LAMC1 & Laminin subunit gamma-1 & 0.56 & 0.000 \\
\hline & NID1 & Nidogen-1 & 0.54 & 0.000 \\
\hline & NID2 & Nidogen-2 & 1.09 & 0.000 \\
\hline & POSTN & Periostin & 1.28 & 0.003 \\
\hline & TENA & Tenascin & 2.55 & 0.022 \\
\hline & TSP4 & Thrombospondin- 4 & 1.34 & 0.048 \\
\hline
\end{tabular}


Table 2. Cont.

\begin{tabular}{|c|c|c|c|c|}
\hline \multicolumn{5}{|c|}{ U/T Extract } \\
\hline \multirow{6}{*}{ Proteoglycans } & ASPN & Asporin & 0.79 & 0.008 \\
\hline & FMOD & Fibromodulin & 0.73 & 0.005 \\
\hline & LUM & Lumican & 0.81 & 0.001 \\
\hline & MIME & Mimecan & 0.54 & 0.008 \\
\hline & PGS1 & Biglycan & 1.05 & 0.002 \\
\hline & PRELP & Prolargin & 0.87 & 0.007 \\
\hline \multirow{5}{*}{$\begin{array}{c}\text { ECM affiliated } \\
\text { proteins }\end{array}$} & ANXA2 & Annexin A2 & 0.42 & 0.005 \\
\hline & ANXA5 & Annexin A5 & 2.28 & 0.002 \\
\hline & HEMO & Hemopexin & 1.59 & 0.007 \\
\hline & ANX11 & Annexin A11 & 0.90 & 0.000 \\
\hline & LEG1 & Galectin-1 & 1.19 & 0.021 \\
\hline \multicolumn{5}{|c|}{ GuHCl Extract } \\
\hline Collagens & COFA1 & Collagen alpha- $1(X V)$ chain & 0.67 & 0.019 \\
\hline $\begin{array}{c}\text { ECM } \\
\text { glycoproteins }\end{array}$ & LAMA5 & Laminin subunit alpha-5 & 0.81 & 0.006 \\
\hline $\begin{array}{c}\text { ECM affiliated } \\
\text { proteins }\end{array}$ & ANXA2 & Annexin A2 & 0.67 & 0.046 \\
\hline
\end{tabular}

\subsection{Ultrastructural Morphology and Morphometrical Evaluation}

To correlate matrisome changes with structural features, gastrocnemius muscles from adult and old mice were collected and processed for morphological and morphometrical analyses using transmission electron microscopy.

The general organization of myofibers in adult and old mice is shown in Figure 2a,c, confirming previous works from our laboratory [28,29]. In both age groups, the endomysium was comprised of a network of collagen fibrils connected to the basement membrane, which was covering the surface of skeletal muscle cells an electrodense sheath (Figure 2b,d).

Morphometrical evaluation of the endomysium thickness performed measuring the distance between the sarcolemma of two adjacent longitudinally sectioned myofibers, revealed no statistically significant difference in adult vs. old mice $(0.685 \pm 0.041$ and $0.611 \pm 0.048 ; p=0.25$, Figure 2e). Instead, the thickness of the basement membrane was significantly higher in old vs. adult mice $(29.72 \pm 0.61 \mathrm{~nm}$ vs. $41.88 \pm 1.07 \mathrm{~nm} ; p<0.001$; Figure 2f), in agreement with the increased amount of basement membrane's components identified by proteomic and immunofluorescence analyses (vide infra).

The extracellular matrix of the perimysium was organized in collagen bundles of different sizes and orientations (Figure 3a,c). In comparison with adult animals, old mice perimysium presented statistically significantly larger collagen bundles $(759.16 \pm 52.05 \mathrm{~nm}$ vs. $1461.66 \pm 75.2 \mathrm{~nm} ; p<0.001$; Figure 3e), which were also more linear (linearity index: $1.05 \pm 0.01$ vs. $1.03 \pm 0.03 ; p=0.03$; Figure 3f). Morphometrical evaluation of the collagen fibrils of the perimysium (Figure $3 \mathrm{~b}, \mathrm{~d}$ ) revealed no statistically significant difference in size in adult vs. old mice $(21.0 \pm 0.65 \mathrm{~nm}$ and $21.4 \pm 0.50 \mathrm{~nm} ; p=0.62$, Figure $3 \mathrm{~g})$. The distance between collagen fibrils was statistically significantly higher in old vs. adult mice $(9.26 \pm 0.92 \mathrm{~nm}$ and $5.84 .45 \pm 0.56 \mathrm{~nm} ; p=0.006$; Figure $3 \mathrm{~h})$. 


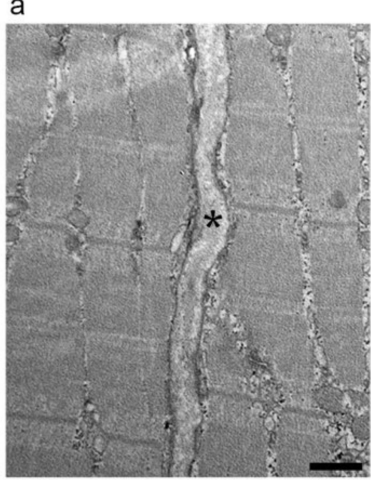

C

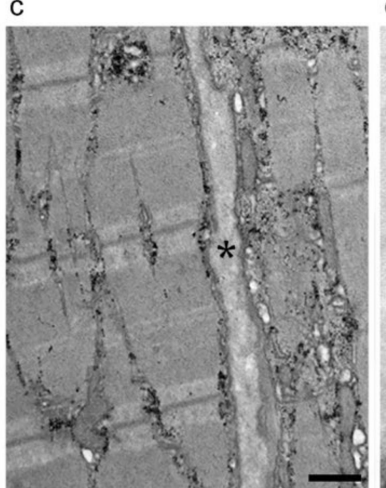

b

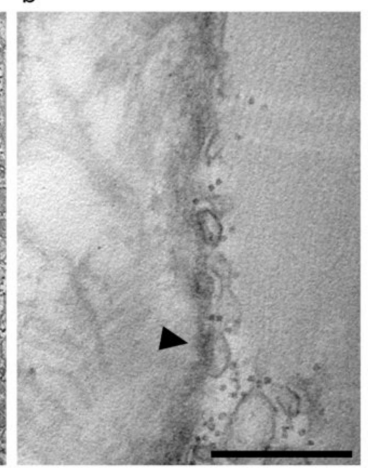

d

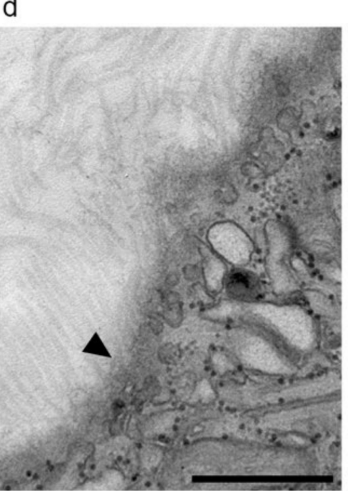

e

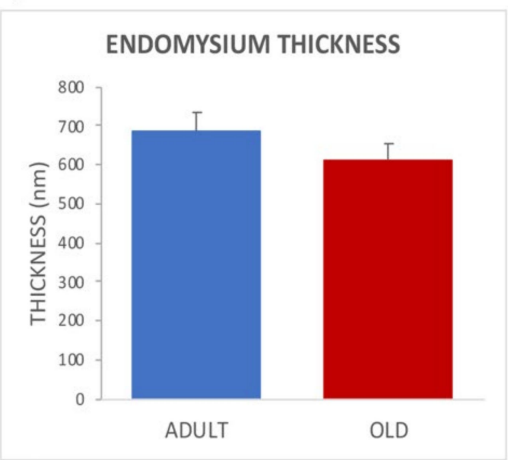

f THICKNESS

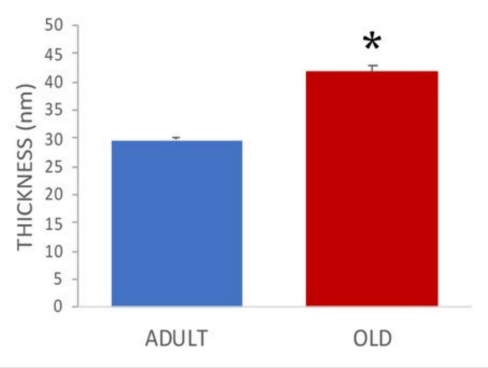

Figure 2. Ultrastructural images of the endomysium in adult $(\mathbf{a}, \mathbf{b})$ and old (c,d) gastrocnemius muscle. *, endomysium; arrowhead, basement membrane. Bars: $500 \mathrm{~nm}$. The endomysium and basement membrane thickness are reported in panels (e) and (f), respectively. ${ }^{*} p<0.001$.

a

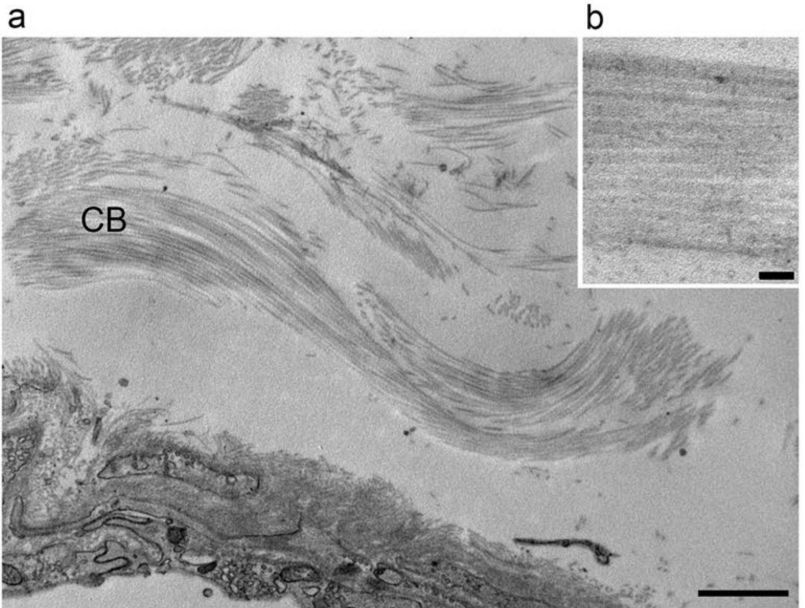

e
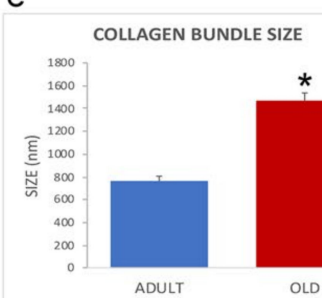

f

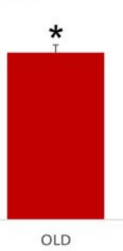

COULAGEN BUNDLE UNEARITY

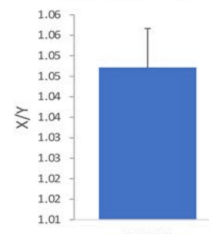

ADULT
C

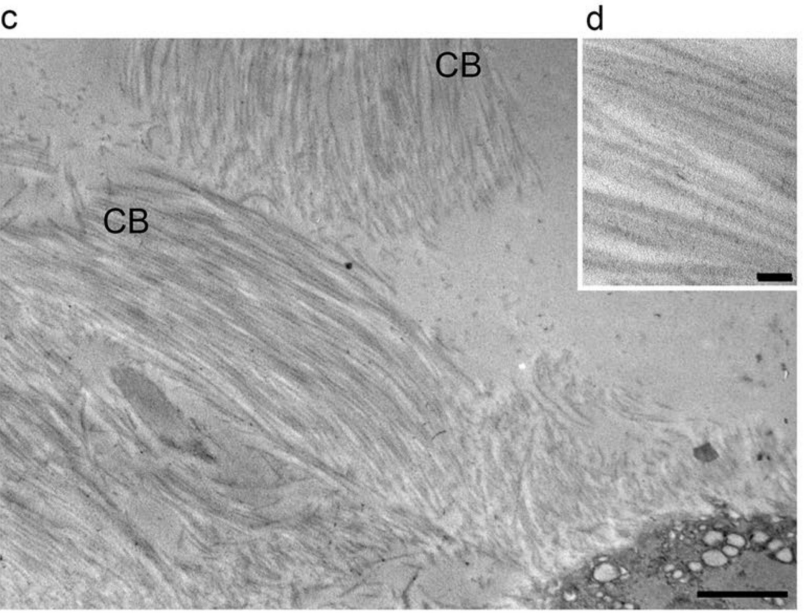

g

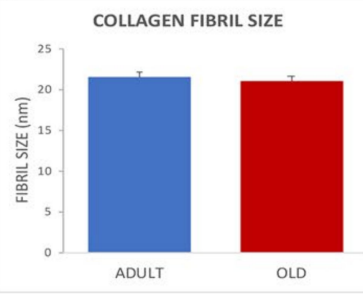

$\mathrm{h}$

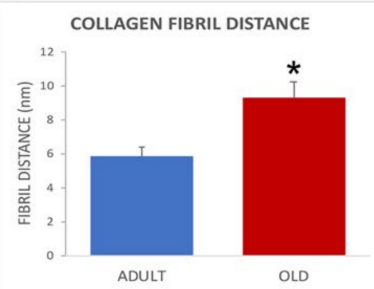

Figure 3. Ultrastructural images (a-d) of the perimysium of adult $(\mathbf{a}, \mathbf{b})$ and old (c,d) gastrocnemius muscle. CB, collagen bundle. (a,c), bars: $1 \mu \mathrm{m}$; (b,d), bars: $100 \mathrm{~nm}$. Morphometric analysis of collagen bundles and collagen fibrils features are reported in the histograms $(\mathbf{e}-\mathbf{h})$. X/Y, ratio between the real length of the collagen bundle profile and the corresponding linear length. ${ }^{*} p<0.05$. 


\subsection{Evaluation of ECM Components by Immunofluorescence}

Immunofluorescence was performed on gastrocnemius cryosections from adult and old mice using specific antibodies directed against the ECM components collagen type VI (as representative interconnection factor between basement membrane and fibrillar collagen) and laminin (as constituent of the basement membrane) (Figure 4). Differences in the immunolabelling distribution were present in the two age groups. In particular, the immunostaining for both collagen type VI (Figure 4a,d) and laminin (Figure 4b,e) appeared more abundant in old vs. adult mice. Qualitative observations were confirmed by quantifying the area covered by fluorescence-positive pixels through a MATLAB routine. Both type VI collagen $(0.1368 \pm 0.0090$ vs. $0.0621 \pm 0.0097, p<0.001$, Figure $4 \mathrm{~g})$ and laminin $(0.1728 \pm 0.0084$ vs. $0.0707 \pm 0.0071 ; p<0.001$, Figure 4 h) were statistically significantly increased in old SM.
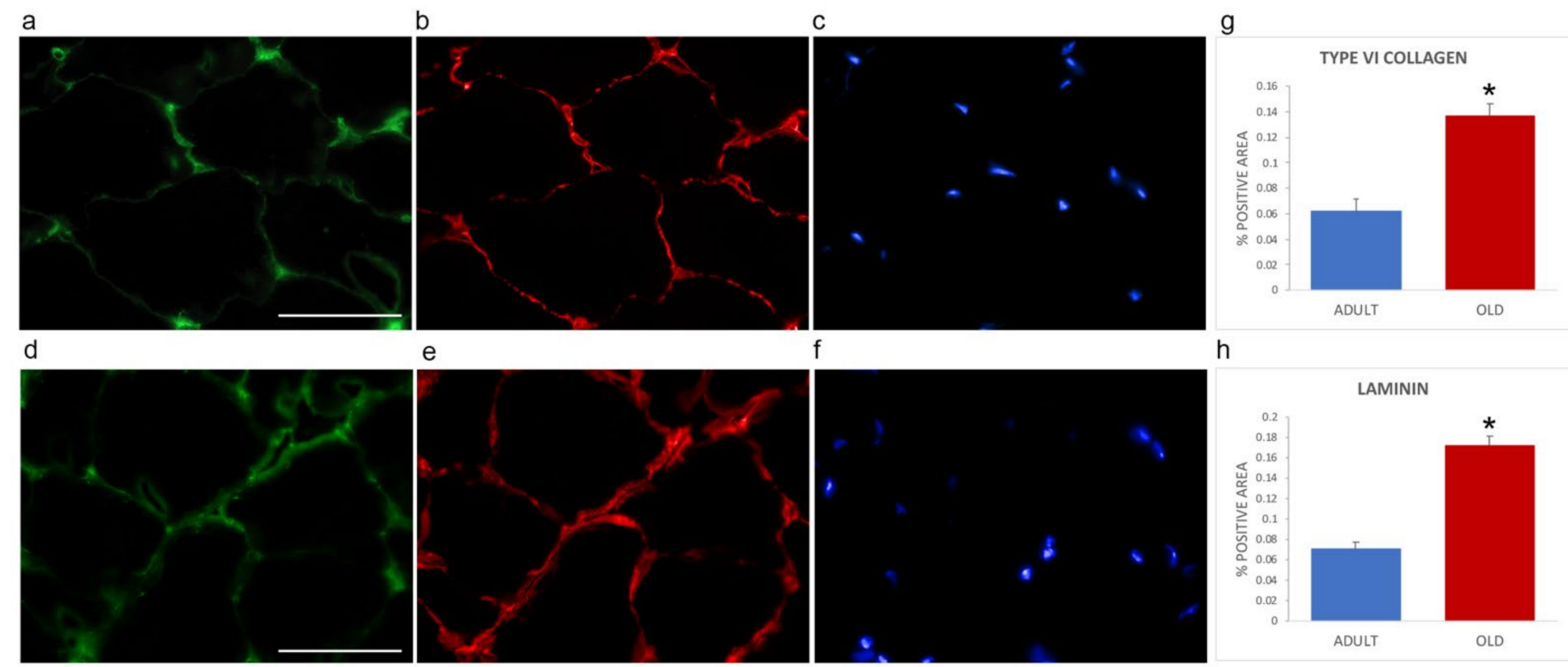

Figure 4. Type VI collagen (a,d) and laminin (b,e) immunolabelling of gastrocnemius cryosections in adult (a-c) and old (d-f) mice. DNA was counterstained with Hoechst (c,f). Bar: $50 \mu \mathrm{m}$. Panels (g) and (h), respectively, show quantification of the immunolabelling for type VI collagen and laminin expressed as $\%$ of total area). ${ }^{*} p<0.001$.

Immunolabelling for type I collagen (as representative of fibrillar collagens) (Figure 5) revealed qualitatively different staining in the two groups of mice. Quantification of the area covered by fluorescence-positive pixels for type I collagen showed no statistically significant difference in the two age groups (adult, $0.0359 \pm 0.0086$; old, $0.0514 \pm 0.0113$; $p=0.275)$. 
a
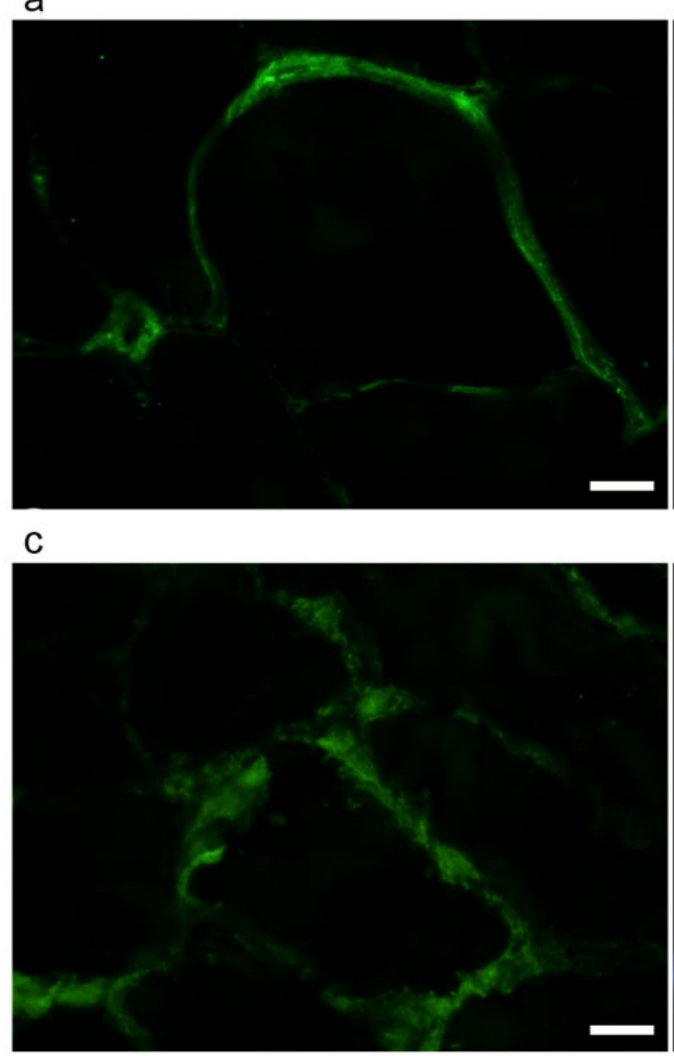

b

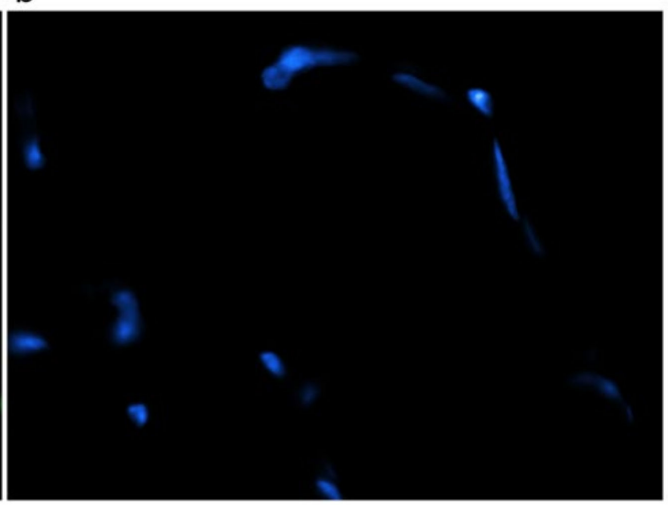

d

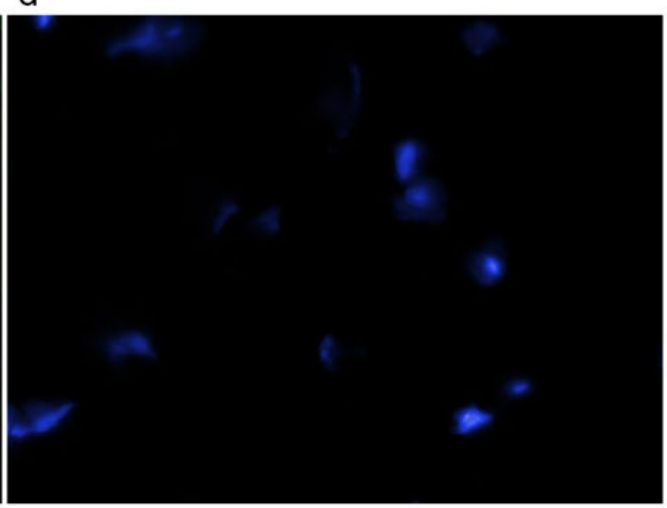

Figure 5. Type I collagen $(\mathbf{a}, \mathbf{c})$ immunolabelling of gastrocnemius cryosections of adult $(\mathbf{a}, \mathbf{b})$ and old $(\mathbf{c}, \mathbf{d})$ mice. DNA was counterstained with Hoechst (b,d). Bar: $10 \mu \mathrm{m}$.

\section{Discussion}

In aging, SM can suffer from low muscle strength and low muscle quality and quantity which may lead to sarcopenia [4].

To characterize and to understand the processes of sarcopenia, many studies using diverse techniques (e.g., computerized tomography, magnetic resonance imaging, electron microscopy, transcriptomic analyses) have mainly focused on changes of the SM mechanical properties and/or alterations of myofibers and SC [38,39]. Moreover, thanks to the development of MS-based proteomics, the intracellular proteins of the aged SM were investigated [40,41]. However, little emphasis has been given to the matrisome, despite growing evidence indicating the ECM as an essential player in SM function. In fact, the matrisome not only constitutes the architectural scaffold for myofibers [42,43], but it is also a reservoir for signaling molecules (e.g., cytokines, chemokines, and growth factors) responding to different stimuli and to stress to maintain cellular homeostasis. Actually, the matrisome is a dynamic compartment mediating outside-in signaling and vice-versa between cells and the surrounding environment [44]. Therefore, in this study, we focused on the matrisome of the whole gastrocnemius muscle by applying a sequential extraction procedure in combination with LC-MS/MS analysis to reveal changes occurring with aging. It is worth remembering that, to date, there is no protocol and/or proteomic technique capable of detecting the entire complexity of the proteome, so our strategy was a compromise between sensitivity and quantitative accuracy. We were able to identify many ECM components, some of them (e.g., collagens, proteoglycans, glycoproteins) being only extracted after strong solubilization conditions such as urea/thiourea and/or guanidinium- $\mathrm{HCl}$.

Our proteomic data demonstrated that changes in matrisome proteins mostly consisted of increased protein abundance in old vs. adult skeletal muscles. 


\subsection{Alteration of Core Matrisome in Aged vs. Adult Mice}

Among the "core matrisome" collagen category, we revealed a significant age-dependent increase of collagen type IV and VI, which was confirmed by quantitative immunofluorescence.

Collagen type VI is present in the epimysial, perimysial, and endomysial interstitium playing a key role in maintaining the SM functional integrity as it represents, together with fibronectin and proteoglycans, the major constituent of the "niche", where the balance between differentiation, self-renewal, and maintenance of muscle regeneration capacity takes place [20,45]. Collagen type VI is typically organized as a heterotrimer of $\alpha 1, \alpha 2$, and $\alpha 3$ chains, but, recently, three new $\alpha$ chains have been described [46]. Since the $\alpha$ chains have a different length and we have demonstrated an increased abundance of only $\alpha 1$ and $\alpha 2$ chain, it could be suggested that an altered ratio among the various collagen type VI chains affects the stability and the supramolecular assembly of the beaded filaments, altering the role of type VI collagen as an anchoring component of basement membranes through the interactions with collagen type IV, biglycan, fibronectin, sarcolemma integrins, and cell surface proteoglycans [46]. Interestingly, thickening of the immunofluorescence staining area for type VI collagen occurred in the gastrocnemius of old mice, further supporting an age-associated alteration of the organization of the anchoring system.

Collagen type IV is a structural molecule of the basement membrane, and its concentration appeared to increase in old muscle, in agreement with previous observations, [47] although with differences depending on muscle type. Collagen type IV accumulation has been shown to drive out SC from their niche, thus potentially contributing to the satellite cell reduction observed in aging $[29,48,49]$.

It is to be noted that, despite the increased amount of type IV and VI collagen contributing to the increased thickness of basement membranes, the endomysium thickness was not changed in adult and old mice. Accordingly, no overall age-associated hypertrophy of the ECM component was previously demonstrated in mouse skeletal muscle [50]. Moreover, in the present study, the amount of fibrillar collagens (i.e., collagen type I, III, and V) in the mouse gastrocnemius muscle did not change with aging. Data reported in the literature are very heterogeneous [51-54], but the loss of muscle performance has been generally related to fibrosis, although, by transcriptomic analysis, collagen genes (i.e., collagen type I and III) appeared significantly downregulated in aging [55]. The discrepancy among different studies may be related to the type or specific portion of muscles analyzed, to sample preparation, and/or to methods applied to quantify collagen (e.g., hydroxyproline measured by HPLC, collagen staining, transcriptomic analysis, proteomic analysis). Moreover, collagen accumulation may be due to excessive production, the altered balance between degradative enzymes and their inhibitors, a combination of the altered ratio between synthesis and degradation, or may be the result of post-translational modification and glycation crosslinking, thus increasing insolubility and lowering the ability of proteolytic enzymes to provide an efficient turnover [56].

Even if we did not observe statistically significant differences in the amount of collagen type I by LC-MS/MS and immunofluorescence, the fibrillar collagen in the perimysium (predominantly collagen type I) [57] of old animals showed a more linear and loosely organized distribution with an increased distance between collagen fibrils that may likely allow the interposition of other ECM constituents. Interestingly, a statistically significant decrease in collagen fiber "tortuosity" [19] and the accumulation of extensively cross-linked collagen together with the reduced size of most myofibers [26,27] have been advocated as a cause of increased muscle stiffness [49,50]. Muscle stiffness has been recently reported to increase, together with ECM amount, in human skeletal muscle of aged vs. young subjects [58]. Accordingly, muscle stiffness is considered a typical hallmark of muscle aging, [50-52,59] as well as the decreased compliance of myofibers in response to tensile loading [19].

Other components of the matrisome are glycoproteins such as laminin, fibronectin, and nidogen, which were detected in higher amounts in old compared to adult SM. Since these glycoproteins act as a bridge between collagen type IV and the sarcolemma of muscle 
fibers [60], their increased amount is consistent with the higher thickness of the basement membrane observed in old animals. Moreover, the increase of laminin during aging can modify the ability of the basement membrane to store and release growth factors and other bioactive molecules required to form the SC niche [61] and to activate $\mathrm{SC}$, thus supporting the previous finding of SC reduced activation potential in old mice [29]. In aged muscle, the shift from functional myofiber repair towards increased extracellular matrix deposition is also associated with changes in the micro-environment and the interactions between ECM glycoproteins as fibronectin, periostin, and tenascin. Interestingly, all of these molecules appeared to increase in the old gastrocnemius muscle.

Fibronectin, for instance, is one of the most widespread glycoproteins of the ECM, playing a role in various processes such as cellular adhesion, spreading and migration, as well as cellular development and differentiation. The increased abundance of fibronectin in old gastrocnemius is in agreement with very recent data demonstrating an association between high fibronectin levels in the aged gastrocnemius muscle, the reduced muscular strength, and myogenic regeneration and differentiation [62].

Periostin is a member of the TGF-beta family of proteins with a putative role associated with pathologic fibrotic events [63]. It is present in the endomysial space and functions upstream and downstream of TGF-beta [64]. Its expression is low in adult tissues, but it is strongly induced and secreted after injury or in dystrophic skeletal muscle [65].

Tenascin is present in all musculoskeletal regions in which high mechanical forces are transmitted, is upregulated in the damage/repair cycle [66] being produced in response to degeneration and the release of growth factors as TGF-beta, and was found to accumulate in the endomysium predominantly in the vicinity of necrotic and regenerating myofibers [67]. As it was also observed in association with atrophy and with age-induced atrophy, it may represent a possible cofactor in the etiology of sarcopenia [68,69].

Interestingly, thrombospondin (TSP1) is also an ECM molecule that was observed to be markedly increased in the aging SM. It modulates cell function by binding to matrix proteins and growth factors altering the properties of ECM and engaging signaling receptors on the cell surface with the activation of latent TGF-beta1. TSP1 promotes aging and it is in turn upregulated by age-related factors as ROS, glucose, and hypoxia and negatively affects mitochondria biogenesis and efficiency as well as endothelial cell proliferation [70,71].

TGF-beta signaling and expression may lead to increased collagens' deposition and to the development of an age-dependent fibrotic environment correlated to fibrin/fibrinogen accumulation, thus suggesting a possible involvement of macrophages within a generalized inflammatory response [72]. These data support the concept that inflammatory and coagulation pathways are increasingly active with aging and can contribute to sarcopenia and frailty [73].

The matrisome structure and organization are also sustained by the interaction between proteoglycans (PGs) and collagens [74]. For instance, biglycan and lumican bind to collagen regulating collagen fibrillogenesis, collagen fibril thickness, and notably interfibrillar spacing, which are important for tissue integrity. Interestingly, in old vs. adult mice, collagen bundles were characterized by the increased distance between fibrils in the presence of similar fibril size. This necessitates further, more detailed analysis of PGs/collagens interactions in aging skeletal muscle. PGs also bind to different growth factors, influencing their bioavailability, cell proliferation, and matrix deposition [75]. In this study, we have observed higher levels of some PGs (e.g., lumican, biglycan, and asporin) in old compared to adult SM. These results are not consistent with those of a recent study, which highlighted a downregulated gene expression of laminin, fibronectin, nidogen, and biglycan in aged SM [55]. This discrepancy is not surprising as many studies have already demonstrated that transcriptomic data had a low correlation with their corresponding proteins [76-78]. For instance, the decoupling of the proteome and transcriptome can be due to (i) posttranscriptional mechanisms regulating protein abundance; (ii) greater stability of proteins compared to transcripts; (iii) decreased proteolytic activity; and (iv) changes in protein synthesis rates. 


\subsection{Alteration of Matrisome-Associated Proteins in Aged vs. Adult Mice}

Among ECM affiliated proteins, annexins (ANX) can play a critical role in cell membrane repair. The sarcolemma is subjected to severe mechanical stress and continuous stretching and the repair machinery is required to preserve and maintain membrane integrity. ANXA6 is a key factor in the repair machinery, and accumulates at the site of sarcolemma injury. This event precedes the activation of ANXA1 and ANXA2. ANXA6 is the only protein that we have observed to be significantly reduced in aging muscle. Reduction of ANXA6 inhibits the aggregation of ANXA1, ANXA2, and ANXA5, thus negatively affecting the repair process [79]. Moreover, an excess of ANXA2 that leaks from injured myofibers can activate muscle-resident fibro-adipogenic precursors that differentiate into adipocytes which gradually lead to muscle degeneration [80].

Muscle repair processes are also modulated by myoblasts-matrix interactions through interaction between laminin and galectin 1 [81]. Since galectin 1 is upregulated in old SM, these data confirm the higher expression that was detected in the signature of the agedependent sarcopenia that is involved in mediating cellular responses to inflammation and apoptosis [82], in the terminal differentiation of myoblasts and the disruption of adhesion of myoblasts to laminin [83].

The homeostasis of the matrisome is finely controlled by different ECM regulators.

Both in PBS and U/T extract we revealed an increase of cathepsin D in old compared to adult SM. Cathepsin D exhibits its activity in the lysosome, but when the cells break it is released in the extracellular space. This molecule has been recently proposed as a sarcopenia biomarker, as its levels were significantly higher in sarcopenic patients than in control subjects [84].

Similarly, matrix metalloproteases (MMPs), ECM-associated enzymes, play a crucial role in regulating the degradation of matrisome molecules [85]. Except for MMP17, which did not change in aging, other MMPs or their inhibitors have been not identified in this study. This could be due to either their low concentration in our experimental conditions or stringent parameters applied in this study or different resolutions of LC-MS/MS, which is crucial for identifying scarce proteins.

By contrast, the inter alpha trypsin inhibitor heavy chain (ITIH4) is increased in aged SM. However, despite the name, it does not possess intrinsic trypsin inhibitory activity, is upregulated by IL-6, and is involved in the stabilization of the extracellular matrix [86], further supporting the occurrence of molecules involved and favoring the progressive accumulation of ECM in the environment surrounding myofibers.

Moreover, among ECM regulators, we have observed an increase of PEDF, a molecule that, inducing endothelial cell apoptosis, exerts antiangiogenic properties. Reduction of blood vessels may negatively affect nutrient and oxygen availability and therefore muscle metabolism. PEDF is upregulated in the aging muscle and is highly expressed in mesenchymal stem cells from old donors [87].

\section{Materials and Methods}

\subsection{Reagents}

All reagents were purchased from Sigma-Aldrich (Merk KGaA, Taufkirchen, Germany) unless otherwise stated.

\subsection{Mice}

Male BALB/c mice aged 12 months (adult, $\mathrm{n}=9$ ) and 24 months (old, $\mathrm{n}=9$ ) were used in this study. The mice, housed in groups of three to four, were maintained under standard conditions $\left(24 \pm 1{ }^{\circ} \mathrm{C}\right.$ ambient temperature, $60 \pm 15 \%$ relative humidity, and $12 \mathrm{~h}$ light/dark cycle) and fed ad libitum with standard commercial chow. The animals had only spontaneous free-moving activity in the cage. 


\subsection{Proteomic Analysis}

\subsubsection{Preparation of Protein Samples for Proteomic Analysis}

The whole gastrocnemius muscles were quickly removed from three mice for each age group and froze for proteomic analysis. Each muscle underwent a three-step sequential extraction (Figure 1a). Frozen muscle was homogenized on ice in phosphate buffer (PBS; 1:10 $w / v$ ) using a glass homogenizer to solubilize cellular and hydrophilic proteins. Samples were centrifuged at $8000 \times g$ for $30 \mathrm{~min}$ at $4{ }^{\circ} \mathrm{C}$. After recovering the supernatants (PBS extract), the resulting pellets were resuspended in urea-thiourea buffer $(1: 10 w / v)$ and incubated at $4{ }^{\circ} \mathrm{C}$ for $24 \mathrm{~h}$ under continuous shaking. After centrifugation at $15,000 \times g$ for $20 \mathrm{~min}$ at $4{ }^{\circ} \mathrm{C}$, the supernatant (U/T extract) was recovered, and the pellet was furthermore homogenized in guanidinium- $\mathrm{HCl}$ buffer $(\mathrm{pH}=8.5,1: 5 \mathrm{w} / \mathrm{v})$, heated at $100{ }^{\circ} \mathrm{C}$ for $10 \mathrm{~min}$ and collected ( $\mathrm{GuHCl}$ extract).

These last steps were provided to maximize the extracellular matrix protein recovery. The protein concentration of each fraction was quantified using the Bradford method. $200 \mu \mathrm{g}$ of proteins/fraction/muscle were subjected to proteomic analysis.

For each fraction, a gel-tube digestion was performed as already described [88]. The proteins embedded in the gel-tube were reduced by incubation with $10 \mathrm{mM}$ dithioerythritol/100 $\mathrm{mM}$ ammonium bicarbonate for $45 \mathrm{~min}$ at $56^{\circ} \mathrm{C}$ and then alkylated with $55 \mathrm{mM}$ iodoacetamide/100 $\mathrm{mM}$ ammonium bicarbonate for $30 \mathrm{~min}$ at RT in the dark. Proteins were digested overnight at $37^{\circ} \mathrm{C}$ in $100 \mathrm{mM}$ ammonium bicarbonate $\mathrm{pH} 8.0$ using sequencing grade trypsin at a 1:100 enzyme-to-protein ratio (Promega, Madison, MI, USA). Peptides were extracted from gel-tubes with $100 \%$ acetonitrile and dried with a SpeedVac (Eppendorf AG, Hamburg, Germany).

\subsubsection{Liquid Chromatography with Tandem Mass Spectrometry (LC-MS/MS)}

Peptides obtained from each fraction were resuspended in water/formic acid solution (95:3:2). A UHPLC ultimate 3000 system coupled online to a Q Exactive Hybrid Quadrupole-Orbitrap Mass Spectrometer (Thermo Fisher Scientific, Waltham, MA, USA) was used, as already described [89] with some modifications. Chromatographic separation of peptides took place in a reverse-phase C18 column $(100 \mathrm{~mm} \times 2.1 \mu \mathrm{m} \mathrm{ID,} 1.9 \mu \mathrm{m}$, HyperG Thermo Fischer Scientific) and elution was performed using a binary system of solvents. Solvent A was $0,1 \%$ formic acid and solvent B was pure acetonitrile. A linear binary gradient was applied to eluate the peptides: $0-20 \%$ solvent B in solvent A for $240 \mathrm{~min}$ and further $60 \mathrm{~min}$ of $20-40 \%$ solvent $\mathrm{B}$ in solvent $\mathrm{A}$. The precursor ion detection was done in an $\mathrm{m} / \mathrm{z}$-range from 400 to 1800 and the acquisition range for fragment ions was $\mathrm{m} / \mathrm{z}$ from 200 to 2000 . The sample injection flow was $0.5 \mathrm{~mL} / \mathrm{min}$, and the column was kept at a constant temperature of $30^{\circ} \mathrm{C}$. Data acquisition was controlled by Xcalibur 2.0.7 Software (Thermo Fisher Scientific, USA). Six independent experiments (three for adult and three for old muscles) were performed and each fraction obtained from each muscle was analyzed in duplicate.

\subsubsection{Data Processing for Protein Identification and Quantification}

Raw MS/MS data (.raw) were inspected using BatMass (v. 0.3.0). Replicates were aligned using FreeStyle (v.1.5) to check the quality of runs. Raw files were further converted by msConvert ProteoWizard (v.3.0.19239) in MGF file using default settings and uploaded to MASCOT server (v.2.7.0) for MS/MS Ion Search. The search was performed using Uniprot (2018_05) restricted to Mus musculus (Taxonomy ID: 10090) and cRAP database to detect most commonly adventitious proteins (https://www.thegpm.org/GPM/index.html (accessed on 6 April 2021:)). Parameters for identification included: (i) trypsin as an enzyme with 1 as maximum missed cleavage; (ii) mass error tolerances for precursor and fragment ions set to $10 \mathrm{ppm}$ and $0.02 \mathrm{Da}$, respectively; (iii) peptide charge $(2+, 3+, 4+)$; (iv) protein mass no restriction; and (v) carbamidomethyl cysteine (C) was set as fixed modification while deamidation of asparagine and glutamine (NQ), oxidation of methionine $(\mathrm{M})$ and cysteine propionamide (C) were considered as variable modifications. Only confident 
peptide identified with a false discovery rate $\leq 1$ and protein with at least one unique peptide were exported.

Mascot results (.dat) obtained for each extraction were imported in Skyline-daily (v.21.0.9.139) to generate the spectral libraries using the following parameters: 0.95 as spectra cut-off score; peptide length of 8-25 amino acids; precursor ion charge $2+, 3+, 4+$; MS1 filters were set to "use high selectivity extraction" with a resolving power of 60,000 at $300 \mathrm{~m} / \mathrm{z}$; repeated and duplicate peptides were removed. Accordingly, to Skyline "DDA peptide search" workflow, raw files (.raw) were imported and matched to spectral libraries to recover precursor ion intensity. Precursor ion intensity is the sum of areas under the curve of extracted ion chromatograms (XICs) containing precursor ion isotope peaks ( $\mathrm{M}$, $\mathrm{M}+1, \mathrm{M}+2$ ) [90]. Fasta files containing proteins with 1\% FDR were imported to Skyline to maintain and fix FDR. Finally, quantitative analysis was performed on proteins with at least two peptides. Indeed, protein inference is mainly based on the unique peptides that are not shared by multiple proteins. However, one peptide can be incorrectly quantified across LC-MS runs, producing improper quantification. In this perspective, first of all, a proteome discovery study was performed releasing a list of proteins identified with at least one unique peptide, and secondly, a label-free quantification study was performed only on proteins identified with at least two peptides to reduce incorrect quantification [37].

\subsection{Bioinformatic Analysis}

We interrogated the MatrisomeDB (http://www.pepchem.org/matrisomedb (accessed on 28 May 2021)) to further characterize and categorize proteins identified in our samples. To date, MatrisomeDB is the most complete database of ECM proteomic data and matrisomal proteins are divided into the "core matrisome" (i.e., glycoproteins, collagens, and proteoglycans) and the "matrisome-associated proteins" (i.e., ECM-affiliated proteins, ECM regulators, and secreted factors) [35].

\subsection{ECM Component Evaluation by Immunofluorescence}

Three adult and three old mice were deeply anesthetized with Tribromoethanol and sacrificed by cervical dislocation. Gastrocnemius muscles were quickly removed and frozen in liquid nitrogen-precooled isopentane. Transversally sectioned $7-\mu \mathrm{m}$ thick cryosections were incubated with $1 \%$ bovine serum albumin, $2 \%$ normal goat serum, $0.3 \%$ Triton ${ }^{\circledR} \mathrm{X}-100$ in phosphate buffer solution (PBS) for $1 \mathrm{~h}$ and immunolabelled with the following probes: a rabbit polyclonal antibody direct against type I collagen, diluted 1:50 (GeneTex, Irvine, CA, USA); a human monoclonal antibody direct against type VI collagen, diluted 1:1000 (ICN Biomedicals, Costa Mesa, CA, USA); rabbit polyclonal antibody direct against laminin, diluted 1:800 (Abcam, Cambridge, UK), in double labeling with anti-collagen type VI.

After washing with PBS, cryosections were stained with the proper secondary antibody: Alexafluor 488-anti-mouse antibodies diluted 1:200 for type VI collagen (Molecular Probes, Invitrogen, CA, USA). Alexafluor 594-anti-rabbit diluted 1:200, for laminin and collagen type I. The cryosections were finally counterstained for DNA with $0.1 \mu \mathrm{g} / \mathrm{mL}$ Hoechst 33258 and mounted in PBS:glycerol (1:1).

An Olympus BX51 microscope equipped with a 100W mercury lamp (Olympus Italia, Milan, Italy) was used under the following conditions: $450-480 \mathrm{~nm}$ excitation filter (excf), $500 \mathrm{~nm}$ dichroic mirror $(\mathrm{dm})$ for Alexa 488; $540 \mathrm{~nm}$ excf, $580 \mathrm{~nm} \mathrm{dm}$, and $620 \mathrm{~nm}$ barrier filter (bf) for Alexa 594; 330-385 nm excf, $400 \mathrm{~nm}$ dm, and $420 \mathrm{~nm}$ bf, for Hoechst 33342. Images were recorded with an Olympus Magnifire digital camera system (Olympus Italia).

A routine was written in MATLAB (2018b version, Mathworks) to quantify the area covered by fluorescence-positive pixels for the total area in four random images acquired at X20 for each animal.

\subsection{Ultrastructural Morphological and Morphometrical Evaluation}

Three adult and three old mice were deeply anesthetized with Tribromoethanol drug and then perfused via the ascending aorta with $0.1 \mathrm{M}$ PBS followed by $4 \%$ paraformalde- 
hyde in PBS. The gastrocnemius muscle was quickly removed, and samples (about $1 \mathrm{~mm}^{3}$ ) were further placed for $2 \mathrm{~h}$ at $4{ }^{\circ} \mathrm{C}$ in $2.5 \%$ glutaraldehyde (Electron Microscopy Sciences, Hatfield, PA, USA) plus $2 \%$ paraformaldehyde in $0.1 \mathrm{M}$ PBS. The samples were then rinsed with PBS, postfixed with $1 \% \mathrm{OsO}_{4}$ (Electron Microscopy Sciences) and $1.5 \%$ potassium ferrocyanide for $2 \mathrm{~h}$ at $4{ }^{\circ} \mathrm{C}$, dehydrated with acetone, and embedded in Epon 812 resin (Electron Microscopy Sciences).

Ultrathin sections (70-90 nm thick) were stained with lead citrate for $1 \mathrm{~min}$ and observed in a Philips Morgagni transmission electron microscope operating at $80 \mathrm{kV}$ and equipped with a Megaview III camera for digital image acquisition.

The morphometric evaluation of the endomysium thickness was performed on 20 randomly selected electron micrographs $(\times 5600)$ of longitudinally sectioned muscle, measuring the distance between the sarcolemma of two adjacent muscle cells every $1 \mu \mathrm{m}$ of sarcolemma length, for a total of 50 measurements per animal.

For morphometric evaluation of the thickness of the basement membrane, a total of 30 measurements per animal were performed. The thickness of the electrodense sheath covering the myofiber was considered on randomly selected electron micrographs $(\times 36,000)$ of longitudinally sectioned muscles.

The morphometric evaluation of the perimysium collagen bundle size was performed on a total of 10 longitudinally sectioned collagen bundles per animal. The index of collagen bundle linearity $(X / Y$, expressed as the ratio between the real length of the bundle profile and the corresponding linear length) was assessed on a total of 30 longitudinally sectioned collagen bundles per age group.

For morphometric evaluation of collagen fibrils, measurement of fibril size, as well as the distance between single collagen fibrils, was performed on a total of 100 longitudinally sectioned collagen fibrils per age group.

All measurements were made by using the Radius software for image acquisition and elaboration implemented in the Philips Morgagni transmission electron microscope.

\subsection{Statistical Analysis}

Statistical analysis of proteomic data was performed using Skyline group comparison tool, set as follows: normalization of runs was performed using "Equilize Medians" with 0.95 as the confidence level; Tukey's Median Polish was set as the summary method. The comparison was set comparing the value obtained in old skeletal muscle against those of adult samples. Proteins with a fold change $>1.5$ or $<0.66$ and a $p$ value $<0.05$ were significantly up-and down-regulated, respectively.

Data on the percentage of fluorescent (positive) areas for laminin, collagen type VI, and type I and data of morphometrical evaluation of transmission electron microscopy images for endomysium size, basement membrane thickness, collagen bundle size and linearity, collagen fibril size, and distance were pooled according to the age group and presented as mean \pm SEM. The Shapiro-Wilk test showed that data were not normally distributed $(p<0.001)$. Consequently, the subsequent statistical analysis was performed using the non-parametric Mann-Whitney test, setting statistical significance at $p$ value $\leq 0.05$. The IBM-SPSS (v.25, Armonk, NY, USA) statistical package was used for all analyses.

\section{Conclusions}

This study provided the first characterization of the matrisome in the aging gastrocnemius muscle and highlights the higher age-dependent abundance of several identified ECM components (Figure 6). 


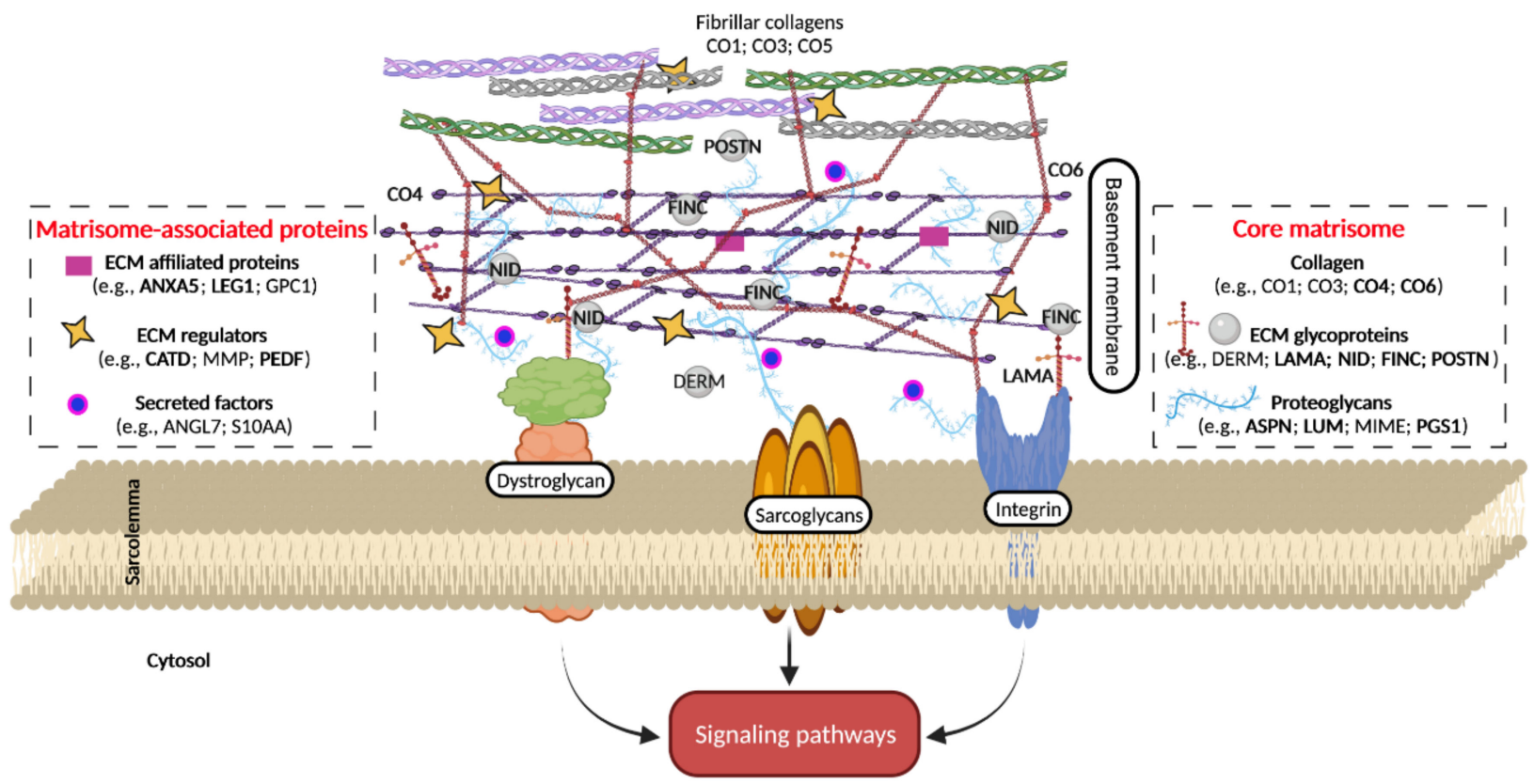

Figure 6. Schematic representation of matrix-sarcolemma axis of skeletal muscle fibre. Proteins differentially expressed between old and adult SM are reported in bold. ANGL7, angiopoietin-related protein 7; ANX, annexin; ASPN, asporin; CO, collagen; CATD, cathepsin D; DERM, dermatopontin; FINC, fibronectin; GPC1, Glypican 1; LAMA, laminin; LEG1, galectin 1; LUM, lumican; MMP, matrix metalloproteinase; MIME, mimecan; NID, nidogen; PEDF, pigment epitheliumderived factor; PGS1, biglycan; POSTN, periostin; S10AA, protein S100-A10.

Since interactions between ECM molecules and between ECM and sarcolemma provide not only structural support but also a mechano-sensing transduction system and a source of cytokines and growth factors, the deepen insight on the matrisome in the aged SM can pave the way for a better understanding of the synergic interplay of the whole extracellular environment and of the mechanisms that can contribute to the age-dependent muscle dysfunction by hindering, for instance, fiber contractility [91], lateral force transmission [92,93], tissue stiffness [49,50], and satellite cell function [12] through ECM-driven signaling pathways.

Supplementary Materials: The following are available online at https:/ /www.mdpi.com/article/ 10.3390/ijms221910564/s1. Table S1: List of identified proteins in each extract; Table S2: quantification of matrisome proteins identified with at least two peptides.

Author Contributions: Conceptualization, F.B. (Federica Boraldi) and M.M.; formal analysis, F.D.L., B.C., F.B. (Federica Boraldi), and F.B. (Federico Boschi); investigation, F.D.L., B.C. and M.A.L.; data curation, M.M. and F.B. (Federica Boraldi); writing-original draft preparation, F.D.L. and B.C.; writing-review and editing, F.B. (Federica Boraldi), C.Z. and D.Q.; supervision, D.Q.; funding acquisition, F.B. (Federica Boraldi) and C.Z. All authors have read and agreed to the published version of the manuscript.

Funding: This research was funded by FAR_DIP 2020 (protocol n ${ }^{\circ}$ E42F20000190001) to F.B. (Federica Boraldi) and Departmental funding (FUR) to C.Z.

Institutional Review Board Statement: Animals were handled according to the regulations of the Italian Ministry of Health (DL 4 March 2014, n. 26) and to the European Communities Council (Directive 63/2010/EU of the European Parliament and the Council) directives. The experimental protocol was approved by the Italian Ministry of Health (Ref.: 538/2015-PR).

Informed Consent Statement: Not applicable.

Data Availability Statement: The mass spectrometry proteomics data have been deposited to the ProteomeXchange Consortium via the PRIDE partner repository with the dataset identifier PXD027895. 
Acknowledgments: The authors wish to thank the "Fondazione Cassa di Risparmio di Modena" for funding Q Exactive Hybrid Quadrupole-Orbitrap Mass Spectrometer at CIGS, UNIMORE.

Conflicts of Interest: The authors declare no conflict of interest.

\section{References}

1. Rowland, L.A.; Bal, N.C.; Periasamy, M. The Role of Skeletal-Muscle-Based Thermogenic Mechanisms in Vertebrate Endothermy. Biol. Rev. Camb. Philos. Soc. 2015, 90, 1279-1297. [CrossRef] [PubMed]

2. Baskin, K.K.; Winders, B.R.; Olson, E.N. Muscle as a "Mediator" of Systemic Metabolism. Cell Metab. 2015, 21, 237-248. [CrossRef] [PubMed]

3. Cruz-Jentoft, A.J.; Sayer, A.A. Sarcopenia. Lancet 2019, 393, 2636-2646. [CrossRef]

4. Cruz-Jentoft, A.J.; Bahat, G.; Bauer, J.; Boirie, Y.; Bruyère, O.; Cederholm, T.; Cooper, C.; Landi, F.; Rolland, Y.; Sayer, A.A.; et al. Sarcopenia: Revised European Consensus on Definition and Diagnosis. Age Ageing 2019, 48, 16-31. [CrossRef]

5. Marty, E.; Liu, Y.; Samuel, A.; Or, O.; Lane, J. A Review of Sarcopenia: Enhancing Awareness of an Increasingly Prevalent Disease. Bone 2017, 105, 276-286. [CrossRef] [PubMed]

6. Walston, J.D. Sarcopenia in Older Adults. Curr. Opin. Rheumatol. 2012, 24, 623-627. [CrossRef] [PubMed]

7. Etienne, J.; Liu, C.; Skinner, C.M.; Conboy, M.J.; Conboy, I.M. Skeletal Muscle as an Experimental Model of Choice to Study Tissue Aging and Rejuvenation. Skelet. Muscle 2020, 10, 4. [CrossRef] [PubMed]

8. Domingues-Faria, C.; Vasson, M.-P.; Goncalves-Mendes, N.; Boirie, Y.; Walrand, S. Skeletal Muscle Regeneration and Impact of Aging and Nutrition. Ageing Res. Rev. 2016, 26, 22-36. [CrossRef]

9. Melouane, A.; Yoshioka, M.; St-Amand, J. Extracellular Matrix/Mitochondria Pathway: A Novel Potential Target for Sarcopenia. Mitochondrion 2020, 50, 63-70. [CrossRef]

10. Cade, W.T.; Yarasheski, K.E. Metabolic and Molecular Aspects of Sarcopenia. In Principles of Molecular Medicine; Runge, M.S., Patterson, C., Eds.; Humana Press: Totowa, NJ, USA, 2006; pp. 529-534. ISBN 978-1-59259-963-9.

11. McCormick, R.; Vasilaki, A. Age-Related Changes in Skeletal Muscle: Changes to Life-Style as a Therapy. Biogerontology 2018, 19, 519-536. [CrossRef]

12. Thomas, K.; Engler, A.J.; Meyer, G.A. Extracellular Matrix Regulation in the Muscle Satellite Cell Niche. Connect. Tissue Res. 2015, 56, 1-8. [CrossRef] [PubMed]

13. Zhang, W.; Liu, Y.; Zhang, H. Extracellular Matrix: An Important Regulator of Cell Functions and Skeletal Muscle Development. Cell Biosci. 2021, 11, 65. [CrossRef] [PubMed]

14. Street, S.F. Lateral Transmission of Tension in Frog Myofibers: A Myofibrillar Network and Transverse Cytoskeletal Connections Are Possible Transmitters. J. Cell Physiol. 1983, 114, 346-364. [CrossRef] [PubMed]

15. Thorsteinsdóttir, S.; Deries, M.; Cachaço, A.S.; Bajanca, F. The Extracellular Matrix Dimension of Skeletal Muscle Development. Dev. Biol. 2011, 354, 191-207. [CrossRef] [PubMed]

16. Calve, S.; Odelberg, S.J.; Simon, H.-G. A Transitional Extracellular Matrix Instructs Cell Behavior during Muscle Regeneration. Dev. Biol. 2010, 344, 259-271. [CrossRef]

17. Kragstrup, T.W.; Kjaer, M.; Mackey, A.L. Structural, Biochemical, Cellular, and Functional Changes in Skeletal Muscle Extracellular Matrix with Aging. Scand. J. Med. Sci. Sports 2011, 21, 749-757. [CrossRef]

18. Trensz, F.; Lucien, F.; Couture, V.; Söllrald, T.; Drouin, G.; Rouleau, A.-J.; Grandbois, M.; Lacraz, G.; Grenier, G. Increased Microenvironment Stiffness in Damaged Myofibers Promotes Myogenic Progenitor Cell Proliferation. Skelet. Muscle 2015, 5, 5. [CrossRef]

19. Stearns-Reider, K.M.; D'Amore, A.; Beezhold, K.; Rothrauff, B.; Cavalli, L.; Wagner, W.R.; Vorp, D.A.; Tsamis, A.; Shinde, S.; Zhang, C.; et al. Aging of the Skeletal Muscle Extracellular Matrix Drives a Stem Cell Fibrogenic Conversion. Aging Cell 2017, 16, 518-528. [CrossRef]

20. Urciuolo, A.; Quarta, M.; Morbidoni, V.; Gattazzo, F.; Molon, S.; Grumati, P.; Montemurro, F.; Tedesco, F.S.; Blaauw, B.; Cossu, G.; et al. Collagen VI Regulates Satellite Cell Self-Renewal and Muscle Regeneration. Nat. Commun. 2013, 4, 1964. [CrossRef]

21. Højlund, K.; Yi, Z.; Hwang, H.; Bowen, B.; Lefort, N.; Flynn, C.R.; Langlais, P.; Weintraub, S.T.; Mandarino, L.J. Characterization of the Human Skeletal Muscle Proteome by One-Dimensional Gel Electrophoresis and HPLC-ESI-MS/MS. Mol. Cell Proteom. 2008, 7, 257-267. [CrossRef]

22. Lang, F.; Aravamudhan, S.; Nolte, H.; Türk, C.; Hölper, S.; Müller, S.; Günther, S.; Blaauw, B.; Braun, T.; Krüger, M. Dynamic Changes in the Mouse Skeletal Muscle Proteome during Denervation-Induced Atrophy. Dis. Model. Mech. 2017, 10, 881-896. [CrossRef]

23. Deshmukh, A.S.; Murgia, M.; Nagaraj, N.; Treebak, J.T.; Cox, J.; Mann, M. Deep Proteomics of Mouse Skeletal Muscle Enables Quantitation of Protein Isoforms, Metabolic Pathways, and Transcription Factors. Mol. Cell Proteom. 2015, 14, 841-853. [CrossRef] [PubMed]

24. Ubaida-Mohien, C.; Lyashkov, A.; Gonzalez-Freire, M.; Tharakan, R.; Shardell, M.; Moaddel, R.; Semba, R.D.; Chia, C.W.; Gorospe, M.; Sen, R.; et al. Discovery Proteomics in Aging Human Skeletal Muscle Finds Change in Spliceosome, Immunity, Proteostasis and Mitochondria. eLife 2019, 8, e49874. [CrossRef] [PubMed]

25. Jacobson, K.R.; Lipp, S.; Acuna, A.; Leng, Y.; Bu, Y.; Calve, S. Comparative Analysis of the Extracellular Matrix Proteome across the Myotendinous Junction. J. Proteome Res. 2020, 19, 3955-3967. [CrossRef] [PubMed] 
26. Malatesta, M.; Fattoretti, P.; Giagnacovo, M.; Pellicciari, C.; Zancanaro, C. Physical Training Modulates Structural and Functional Features of Cell Nuclei in Type II Myofibers of Old Mice. Rejuvenation Res. 2011, 14, 543-552. [CrossRef]

27. Zancanaro, C.; Mariotti, R.; Perdoni, F.; Nicolato, E.; Malatesta, M. Physical Training Is Associated with Changes in Nuclear Magnetic Resonance and Morphometrical Parameters of the Skeletal Muscle in Senescent Mice. Eur. J. Histochem. 2007, 51, 305-310. [CrossRef]

28. Costanzo, M.; Cisterna, B.; Malatesta, M. Effect of Physical Exercise on the Ultrastructural Features of Skeletal Muscle Mitochondria in Old Mice. Microscopie 2013, 20, 37-43. [CrossRef]

29. Cisterna, B.; Giagnacovo, M.; Costanzo, M.; Fattoretti, P.; Zancanaro, C.; Pellicciari, C.; Malatesta, M. Adapted Physical Exercise Enhances Activation and Differentiation Potential of Satellite Cells in the Skeletal Muscle of Old Mice. J. Anat. 2016, 228, 771-783. [CrossRef]

30. Malatesta, M.; Giagnacovo, M.; Cardani, R.; Meola, G.; Pellicciari, C. RNA Processing Is Altered in Skeletal Muscle Nuclei of Patients Affected by Myotonic Dystrophy. Histochem. Cell Biol. 2011, 135, 419-425. [CrossRef]

31. Malva, A.D.; Albenzio, M.; Santillo, A.; Russo, D.; Figliola, L.; Caroprese, M.; Marino, R. Methods for Extraction of Muscle Proteins from Meat and Fish Using Denaturing and Nondenaturing Solutions. J. Food Qual. 2018, 2018, e8478471. [CrossRef]

32. Wilson, R.; Diseberg, A.F.; Gordon, L.; Zivkovic, S.; Tatarczuch, L.; Mackie, E.J.; Gorman, J.J.; Bateman, J.F. Comprehensive Profiling of Cartilage Extracellular Matrix Formation and Maturation Using Sequential Extraction and Label-Free Quantitative Proteomics. Mol. Cell Proteom. 2010, 9, 1296-1313. [CrossRef] [PubMed]

33. Sato, N.; Taniguchi, T.; Goda, Y.; Kosaka, H.; Higashino, K.; Sakai, T.; Katoh, S.; Yasui, N.; Sairyo, K.; Taniguchi, H. Proteomic Analysis of Human Tendon and Ligament: Solubilization and Analysis of Insoluble Extracellular Matrix in Connective Tissues. J. Proteome Res. 2016, 15, 4709-4721. [CrossRef] [PubMed]

34. Naba, A.; Clauser, K.R.; Ding, H.; Whittaker, C.A.; Carr, S.A.; Hynes, R.O. The Extracellular Matrix: Tools and Insights for the "Omics" Era. Matrix Biol. 2016, 49, 10-24. [CrossRef] [PubMed]

35. Shao, X.; Taha, I.N.; Clauser, K.R.; Gao, Y.T.; Naba, A. MatrisomeDB: The ECM-Protein Knowledge Database. Nucleic Acids Res. 2020, 48, D1136-D1144. [CrossRef] [PubMed]

36. Théron, L.; Gueugneau, M.; Coudy, C.; Viala, D.; Bijlsma, A.; Butler-Browne, G.; Maier, A.; Béchet, D.; Chambon, C. Label-Free Quantitative Protein Profiling of Vastus Lateralis Muscle during Human Aging. Mol. Cell Proteom. 2014, 13, 283-294. [CrossRef] [PubMed]

37. Tsai, T.-H.; Choi, M.; Banfai, B.; Liu, Y.; MacLean, B.X.; Dunkley, T.; Vitek, O. Selection of Features with Consistent Profiles Improves Relative Protein Quantification in Mass Spectrometry Experiments. Mol. Cell Proteom. 2020, 19, 944-959. [CrossRef]

38. Malatesta, M.; Perdoni, F.; Muller, S.; Zancanaro, C.; Pellicciari, C. Nuclei of Aged Myofibres Undergo Structural and Functional Changes Suggesting Impairment in RNA Processing. Eur. J. Histochem. 2009, 53, 97-106. [CrossRef]

39. Zahn, J.M.; Sonu, R.; Vogel, H.; Crane, E.; Mazan-Mamczarz, K.; Rabkin, R.; Davis, R.W.; Becker, K.G.; Owen, A.B.; Kim, S.K. Transcriptional Profiling of Aging in Human Muscle Reveals a Common Aging Signature. PLoS Genet. 2006, 2, e115. [CrossRef]

40. Ohlendieck, K. Proteomics of Skeletal Muscle Differentiation, Neuromuscular Disorders and Fiber Aging. Expert Rev. Proteom. 2010, 7, 283-296. [CrossRef]

41. Doran, P.; Donoghue, P.; O'Connell, K.; Gannon, J.; Ohlendieck, K. Proteomics of Skeletal Muscle Aging. Proteomics 2009, 9, 989-1003. [CrossRef]

42. Ahmad, K.; Shaikh, S.; Ahmad, S.S.; Lee, E.J.; Choi, I. Cross-Talk Between Extracellular Matrix and Skeletal Muscle: Implications for Myopathies. Front. Pharmacol. 2020, 11, 142. [CrossRef]

43. Ahmad, K.; Lee, E.J.; Moon, J.S.; Park, S.-Y.; Choi, I. Multifaceted Interweaving Between Extracellular Matrix, Insulin Resistance, and Skeletal Muscle. Cells 2018, 7, 148. [CrossRef]

44. Hynes, R.O. The Extracellular Matrix: Not Just Pretty Fibrils. Science 2009, 326, 1216-1219. [CrossRef]

45. Muñoz-Cánoves, P.; Neves, J.; Sousa-Victor, P. Understanding Muscle Regenerative Decline with Aging: New Approaches to Bring Back Youthfulness to Aged Stem Cells. FEBS J. 2020, 287, 406-416. [CrossRef]

46. Fitzgerald, J.; Holden, P.; Hansen, U. The Expanded Collagen VI Family: New Chains and New Questions. Connect. Tissue Res. 2013, 54, 345-350. [CrossRef]

47. Kovanen, V.; Suominen, H.; Risteli, J.; Risteli, L. Type IV Collagen and Laminin in Slow and Fast Skeletal Muscle in Rats-Effects of Age and Life-Time Endurance Training. Coll. Relat. Res. 1988, 8, 145-153. [CrossRef]

48. Snow, M.H. The Effects of Aging on Satellite Cells in Skeletal Muscles of Mice and Rats. Cell Tissue Res. 1977, 185, 399-408. [CrossRef] [PubMed]

49. Csapo, R.; Gumpenberger, M.; Wessner, B. Skeletal Muscle Extracellular Matrix-What Do We Know About Its Composition, Regulation, and Physiological Roles? A Narrative Review. Front. Physiol. 2020, 11, 253. [CrossRef] [PubMed]

50. Wood, L.K.; Kayupov, E.; Gumucio, J.P.; Mendias, C.L.; Claflin, D.R.; Brooks, S.V. Intrinsic Stiffness of Extracellular Matrix Increases with Age in Skeletal Muscles of Mice. J. Appl. Physiol. 2014, 117, 363-369. [CrossRef]

51. Alnaqeeb, M.A.; Al Zaid, N.S.; Goldspink, G. Connective Tissue Changes and Physical Properties of Developing and Ageing Skeletal Muscle. J. Anat. 1984, 139 Pt 4, 677-689. [PubMed]

52. Lacraz, G.; Rouleau, A.-J.; Couture, V.; Söllrald, T.; Drouin, G.; Veillette, N.; Grandbois, M.; Grenier, G. Increased Stiffness in Aged Skeletal Muscle Impairs Muscle Progenitor Cell Proliferative Activity. PLoS ONE 2015, 10, e0136217. [CrossRef] [PubMed] 
53. Kovanen, V.; Suominen, H. Age- and Training-Related Changes in the Collagen Metabolism of Rat Skeletal Muscle. Eur. J. Appl. Physiol. Occup. Physiol. 1989, 58, 765-771. [CrossRef] [PubMed]

54. Haus, J.M.; Carrithers, J.A.; Trappe, S.W.; Trappe, T.A. Collagen, Cross-Linking, and Advanced Glycation End Products in Aging Human Skeletal Muscle. J. Appl. Physiol. 2007, 103, 2068-2076. [CrossRef] [PubMed]

55. Chen, W.-J.; Lin, I.-H.; Lee, C.-W.; Chen, Y.-F. Aged Skeletal Muscle Retains the Ability to Remodel Extracellular Matrix for Degradation of Collagen Deposition after Muscle Injury. Int. J. Mol. Sci. 2021, 22, 2123. [CrossRef]

56. Gillies, A.R.; Lieber, R.L. Structure and Function of the Skeletal Muscle Extracellular Matrix. Muscle Nerve 2011, 44, 318-331. [CrossRef] [PubMed]

57. Gelse, K.; Pöschl, E.; Aigner, T. Collagens—Structure, Function, and Biosynthesis. Adv. Drug Deliv. Rev. 2003, 55, 1531-1546. [CrossRef]

58. Pavan, P.; Monti, E.; Bondí, M.; Fan, C.; Stecco, C.; Narici, M.; Reggiani, C.; Marcucci, L. Alterations of Extracellular Matrix Mechanical Properties Contribute to Age-Related Functional Impairment of Human Skeletal Muscles. Int. J. Mol. Sci. 2020, 21, 3992. [CrossRef]

59. Gosselin, L.E.; Martinez, D.A.; Vailas, A.C.; Sieck, G.C. Passive Length-Force Properties of Senescent Diaphragm: Relationship with Collagen Characteristics. J. Appl. Physiol. 1994, 76, 2680-2685. [CrossRef]

60. Hohenester, E.; Yurchenco, P.D. Laminins in Basement Membrane Assembly. Cell Adhes. Migr. 2013, 7, 56-63. [CrossRef]

61. Grzelkowska-Kowalczyk, K. The Importance of Extracellular Matrix in Skeletal Muscle Development and Function; IntechOpen: London, UK, 2016; ISBN 978-953-51-2416-0.

62. Sosa, P.; Alcalde-Estévez, E.; Asenjo-Bueno, A.; Plaza, P.; Carrillo-López, N.; Olmos, G.; López-Ongil, S.; Ruiz-Torres, M.P. Aging-Related Hyperphosphatemia Impairs Myogenic Differentiation and Enhances Fibrosis in Skeletal Muscle. J. Cachexia Sarcopenia Muscle 2021. [CrossRef] [PubMed]

63. Conway, S.J.; Izuhara, K.; Kudo, Y.; Litvin, J.; Markwald, R.; Ouyang, G.; Arron, J.R.; Holweg, C.T.J.; Kudo, A. The Role of Periostin in Tissue Remodeling across Health and Disease. Cell Mol. Life Sci. 2014, 71, 1279-1288. [CrossRef] [PubMed]

64. Horiuchi, K.; Amizuka, N.; Takeshita, S.; Takamatsu, H.; Katsuura, M.; Ozawa, H.; Toyama, Y.; Bonewald, L.F.; Kudo, A. Identification and Characterization of a Novel Protein, Periostin, with Restricted Expression to Periosteum and Periodontal Ligament and Increased Expression by Transforming Growth Factor Beta. J. Bone Miner. Res. 1999, 14, 1239-1249. [CrossRef] [PubMed]

65. Lorts, A.; Schwanekamp, J.A.; Baudino, T.A.; McNally, E.M.; Molkentin, J.D. Deletion of Periostin Reduces Muscular Dystrophy and Fibrosis in Mice by Modulating the Transforming Growth Factor- $\beta$ Pathway. Proc. Natl. Acad. Sci. USA 2012, 109, 10978-10983. [CrossRef]

66. Järvinen, T.A.; Kannus, P.; Järvinen, T.L.; Jozsa, L.; Kalimo, H.; Järvinen, M. Tenascin-C in the Pathobiology and Healing Process of Musculoskeletal Tissue Injury. Scand. J. Med. Sci. Sports 2000, 10, 376-382. [CrossRef]

67. Settles, D.L.; Cihak, R.A.; Erickson, H.P. Tenascin-C Expression in Dystrophin-Related Muscular Dystrophy. Muscle Nerve 1996, 19, 147-154. [CrossRef]

68. Schoser, B.G.; Faissner, A.; Goebel, H.H. Immunolocalization of Tenascin-C in Human Type II Fiber Atrophy. J. Mol. Neurosci. 1999, 13, 167-175. [CrossRef]

69. Flück, M.; Mund, S.I.; Schittny, J.C.; Klossner, S.; Durieux, A.-C.; Giraud, M.-N. Mechano-Regulated Tenascin-C Orchestrates Muscle Repair. PNAS 2008, 105, 13662-13667. [CrossRef] [PubMed]

70. Isenberg, J.S.; Roberts, D.D. Thrombospondin-1 in Maladaptive Aging Responses: A Concept Whose Time Has Come. Am. J. Physiol. Cell Physiol. 2020, 319, C45-C63. [CrossRef]

71. Frazier, E.P.; Isenberg, J.S.; Shiva, S.; Zhao, L.; Schlesinger, P.; Dimitry, J.; Abu-Asab, M.S.; Tsokos, M.; Roberts, D.D.; Frazier, W.A. Age-Dependent Regulation of Skeletal Muscle Mitochondria by the Thrombospondin-1 Receptor CD47. Matrix Biol. 2011, 30, 154-161. [CrossRef] [PubMed]

72. Vidal, B.; Serrano, A.L.; Tjwa, M.; Suelves, M.; Ardite, E.; De Mori, R.; Baeza-Raja, B.; Martínez de Lagrán, M.; Lafuste, P.; Ruiz-Bonilla, V.; et al. Fibrinogen Drives Dystrophic Muscle Fibrosis via a TGFbeta/Alternative Macrophage Activation Pathway. Genes Dev. 2008, 22, 1747-1752. [CrossRef]

73. Kanapuru, B.; Ershler, W.B. Inflammation, Coagulation, and the Pathway to Frailty. Am. J. Med. 2009, 122, 605-613. [CrossRef] [PubMed]

74. Ameye, L.; Young, M.F. Mice Deficient in Small Leucine-Rich Proteoglycans: Novel in Vivo Models for Osteoporosis, Osteoarthritis, Ehlers-Danlos Syndrome, Muscular Dystrophy, and Corneal Diseases. Glycobiology 2002, 12, 107R-116R. [CrossRef] [PubMed]

75. Ludwig, M.S. Proteoglycans and Pathophysiology. J. Appl. Physiol. 2007, 103, 735-736. [CrossRef] [PubMed]

76. Yang, H.; Xu, X.; Ma, H.; Jiang, J. Integrative Analysis of Transcriptomics and Proteomics of Skeletal Muscles of the Chinese Indigenous Shaziling Pig Compared with the Yorkshire Breed. BMC Genet. 2016, 17, 80. [CrossRef]

77. Davey, J.R.; Watt, K.I.; Parker, B.L.; Chaudhuri, R.; Ryall, J.G.; Cunningham, L.; Qian, H.; Sartorelli, V.; Sandri, M.; Chamberlain, J.; et al. Integrated Expression Analysis of Muscle Hypertrophy Identifies Asb2 as a Negative Regulator of Muscle Mass. JCI Insight 2016, 1. [CrossRef]

78. Kühl, I.; Miranda, M.; Atanassov, I.; Kuznetsova, I.; Hinze, Y.; Mourier, A.; Filipovska, A.; Larsson, N.-G. Transcriptomic and Proteomic Landscape of Mitochondrial Dysfunction Reveals Secondary Coenzyme Q Deficiency in Mammals. eLife 2017, 6, e30952. [CrossRef] 
79. Croissant, C.; Gounou, C.; Bouvet, F.; Tan, S.; Bouter, A. Annexin-A6 in Membrane Repair of Human Skeletal Muscle Cell: A Role in the Cap Subdomain. Cells 2020, 9, 1742. [CrossRef]

80. Croissant, C.; Carmeille, R.; Brévart, C.; Bouter, A. Annexins and Membrane Repair Dysfunctions in Muscular Dystrophies. Int. J. Mol. Sci. 2021, 22, 5276. [CrossRef]

81. Cooper, D.N.; Barondes, S.H. Evidence for Export of a Muscle Lectin from Cytosol to Extracellular Matrix and for a Novel Secretory Mechanism. J. Cell Biol. 1990, 110, 1681-1691. [CrossRef]

82. Giresi, P.G.; Stevenson, E.J.; Theilhaber, J.; Koncarevic, A.; Parkington, J.; Fielding, R.A.; Kandarian, S.C. Identification of a Molecular Signature of Sarcopenia. Physiol. Genom. 2005, 21, 253-263. [CrossRef]

83. Watt, D.J.; Jones, G.E.; Goldring, K. The Involvement of Galectin-1 in Skeletal Muscle Determination, Differentiation and Regeneration. Glycoconj. J. 2002, 19, 615-619. [CrossRef]

84. L'hôte, C.; Cordier, B.; Labasse, A.; Boileau, C.; Costes, B.; Henrotin, Y. Identification of New Biomarkers for Sarcopenia and Characterization of Cathepsin D Biomarker. JCSM Rapid Commun. 2021, 4, 122-132. [CrossRef]

85. Alameddine, H.S. Matrix Metalloproteinases in Skeletal Muscles: Friends or Foes? Neurobiol. Dis. 2012, 48, 508-518. [CrossRef] [PubMed]

86. Chandler, K.B.; Brnakova, Z.; Sanda, M.; Wang, S.; Stalnaker, S.H.; Bridger, R.; Zhao, P.; Wells, L.; Edwards, N.J.; Goldman, R. Site-Specific Glycan Microheterogeneity of Inter-Alpha-Trypsin Inhibitor Heavy Chain H4. J. Proteome Res. 2014, 13, $3314-3329$. [CrossRef] [PubMed]

87. Liang, H.; Hou, H.; Yi, W.; Yang, G.; Gu, C.; Lau, W.B.; Gao, E.; Ma, X.; Lu, Z.; Wei, X.; et al. Increased Expression of Pigment Epithelium-Derived Factor in Aged Mesenchymal Stem Cells Impairs Their Therapeutic Efficacy for Attenuating Myocardial Infarction Injury. Eur. Heart J. 2013, 34, 1681-1690. [CrossRef] [PubMed]

88. Boraldi, F.; Lofaro, F.D.; Accorsi, A.; Ross, E.; Malagoli, D. Toward the Molecular Deciphering of Pomacea Canaliculata Immunity: First Proteomic Analysis of Circulating Hemocytes. Proteomics 2019, 19, e1800314. [CrossRef] [PubMed]

89. Boraldi, F.; Moscarelli, P.; Lofaro, F.D.; Sabia, C.; Quaglino, D. The Mineralization Process of Insoluble Elastin Fibrillar Structures: Ionic Environment vs Degradation. Int. J. Biol. Macromol. 2020, 149, 693-706. [CrossRef]

90. Singhto, N.; Thongboonkerd, V. Exosomes Derived from Calcium Oxalate-Exposed Macrophages Enhance IL-8 Production from Renal Cells, Neutrophil Migration and Crystal Invasion through Extracellular Matrix. J. Proteom. 2018, 185, 64-76. [CrossRef]

91. Azizi, E.; Deslauriers, A.R.; Holt, N.C.; Eaton, C.E. Resistance to Radial Expansion Limits Muscle Strain and Work. Biomech. Model. Mechanobiol. 2017, 16, 1633-1643. [CrossRef]

92. Sharafi, B.; Blemker, S.S. A Mathematical Model of Force Transmission from Intrafascicularly Terminating Muscle Fibers. J. Biomech. 2011, 44, 2031-2039. [CrossRef]

93. Gillies, A.R.; Chapman, M.A.; Bushong, E.A.; Deerinck, T.J.; Ellisman, M.H.; Lieber, R.L. High Resolution Three-Dimensional Reconstruction of Fibrotic Skeletal Muscle Extracellular Matrix. J. Physiol. 2017, 595, 1159-1171. [CrossRef] 